\title{
Assessment of Hydrocarbon Prospectivity in Terai and Siwaliks, Exploration Block 2, Western Nepal
}

\author{
Dharma Raj Khadka \\ Department of Mines and Geology, Kathmandu, Nepal
}

\begin{abstract}
BasinMod 1D software with faulting module is used to model two synthetic wells taken from a geoseismic section in Exploration Block 2 in western Nepal to understand the burial and thermal history of exterior belt (Terai) and Siwalik fold and thrust belt. The study focuses the measured inputs of source and reservoir rocks of Surkhet Group consisting of Swat shale (2\%), TOC and Melpani sandstone porosity (10\%). The geohistory curves show rapid sedimentation and tectonic subsidence. The thermal history is constrained using a $20{ }^{\circ} \mathrm{C} / \mathrm{km}$ geothermal gradient for the exterior belt, whereas for the Siwalik fold and thrust belt, a two-step geothermal gradient is proposed using a $20{ }^{\circ} \mathrm{C} / \mathrm{km}$ for the upper $2,000 \mathrm{~m}$ and $23{ }^{\circ} \mathrm{C} / \mathrm{km}$ below this depth. The modeled values for maturity show that the Surkhet Group lies in the mid mature oil window in the exterior belt, but for the Siwalik fold and thrust belt, the hanging-wall Paleogene wedge is in the early mature stage, whereas the footwall Paleogene wedge is in the late mature stage. Oil generation for the Swat shales started at 6.3 Ma at 3,988 m depth with peak oil generation 2.4-1.3 Ma at 5,435-5,782 $\mathrm{m}$ depth in the exterior belt. However, the Siwalik fold and thrust belt modeling shows that the footwall Swat Formation has no oil generation capacity after the faulting episode, whereas it had been producing oil since about $8.5 \mathrm{Ma}$ at 3,800 $\mathrm{m}$ with main phase of oil generation at about 7 Ma at 4,600 m. The hanging-wall Swat Formation has been in the early mature stage of oil generation since faulting. The timing of structural trap formation window is set to 4.1-1.8 Ma based on geological evidence from the literature. The results show trap formation is more or less contemporaneous with hydrocarbon generation and expulsion and timing will be critical for assessments of the prospectivity.
\end{abstract}

Key words: Siwaliks and Terai, basin modeling, hydrocarbon prospectivity.

\section{Introduction}

The central sector of Himalaya in the Nepalese Siwalik Foreland Basin forms the northern part of the Indo-Gangetic Foreland Basin. The present study area is in the western part of the Nepalese Siwalik Foreland Basin (Fig. 1).

The Paleogene wedge was discovered in Exploration Blocks 2 in western Nepal with the aid of about $500 \mathrm{~km}$ of seismic profiles [1]. The Eocene Swat calcareous and carbonaceous dark shales of marine origin are probably the best potential source rocks in western Nepal. Geochemical analyses show TOC contents greater than $2 \%$ in the Lesser Himalayan outcrops. All samples are of overmature, Type II kerogene, but their initial petroleum potential is unknown [1]. The

Corresponding author: Dharma Raj Khadka, Sr. Div. geologist, research fields: geo-exploration, geological mapping, modeling and reserve characterization. maturity levels in the Siwalik fold and thrust belt and the undeformed external foothills (Terai) have to be analyzed. Petroleum Exploration Block-2, in the Karnali region of western Nepal, has been selected to test burial and thermal models in order to evaluate timing of hydrocarbon generation and expulsion from the Paleogene potential source rocks.

This study aims to generate and model two synthetic wells taken from a cross section in Exploration Block 2. The burial and thermal history of both the Exterior belt (Terai) and Siwalik fold and thrust belt will be modeled by integrating geological data in the synthetic wells with emphasis on the timing of trap formation against hydrocarbon generation and expulsion from the potential source rocks.

The basin modeling is carried out using BasinMod-1D software. Geological data (lithology and thickness of formations) are taken from the geological 


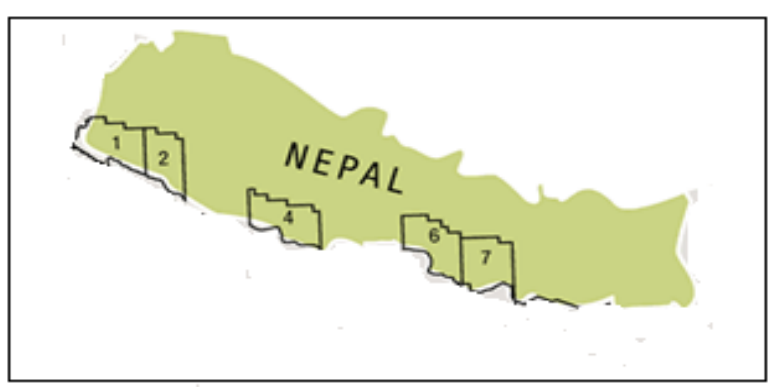

Fig. 1 Location map of present study area, Exploration Block 2.

map and cross section of Petroleum Exploration Block 2, Karnali area, Western Nepal (Scale 1:250,000) [2] based on seismic data interpretation of the western Terai by Digicon Singapore (1993) and Source and Seal Study by AI Consult International Ltd (1993). The section is used for the selection of synthetic well locations, one in the Siwalik fold and thrust belt and another in the exterior foothill belt (Terai). Source rock and reservoir rock information, ages of the formations, heat flow and surface temperature data are all taken from the relevant literature. Geohistory, thermal maturity, tectonic subsidence, petroleum system events and cumulative hydrocarbon generation were modeled based on these input parameters.

\section{Regional Geology}

Nepal is divided into five east-west trending tectonic zones: Tethys Himalaya, Higher Himalaya, Lesser Himalaya, Sub Himalaya (Siwaliks) and Terai (Figs. 2 and 3).

The Tethys Himalayan sequence ranging in age from Cambrian to Paleocene is generally beginning from the top of the Higher Himalayan Zone and extends to the north into Tibet. These fossiliferous rocks are well developed in the area north of the Annapurna and Manaslu ranges in central Nepal and consist of metasediments that overlie the Higher Himalayan zone

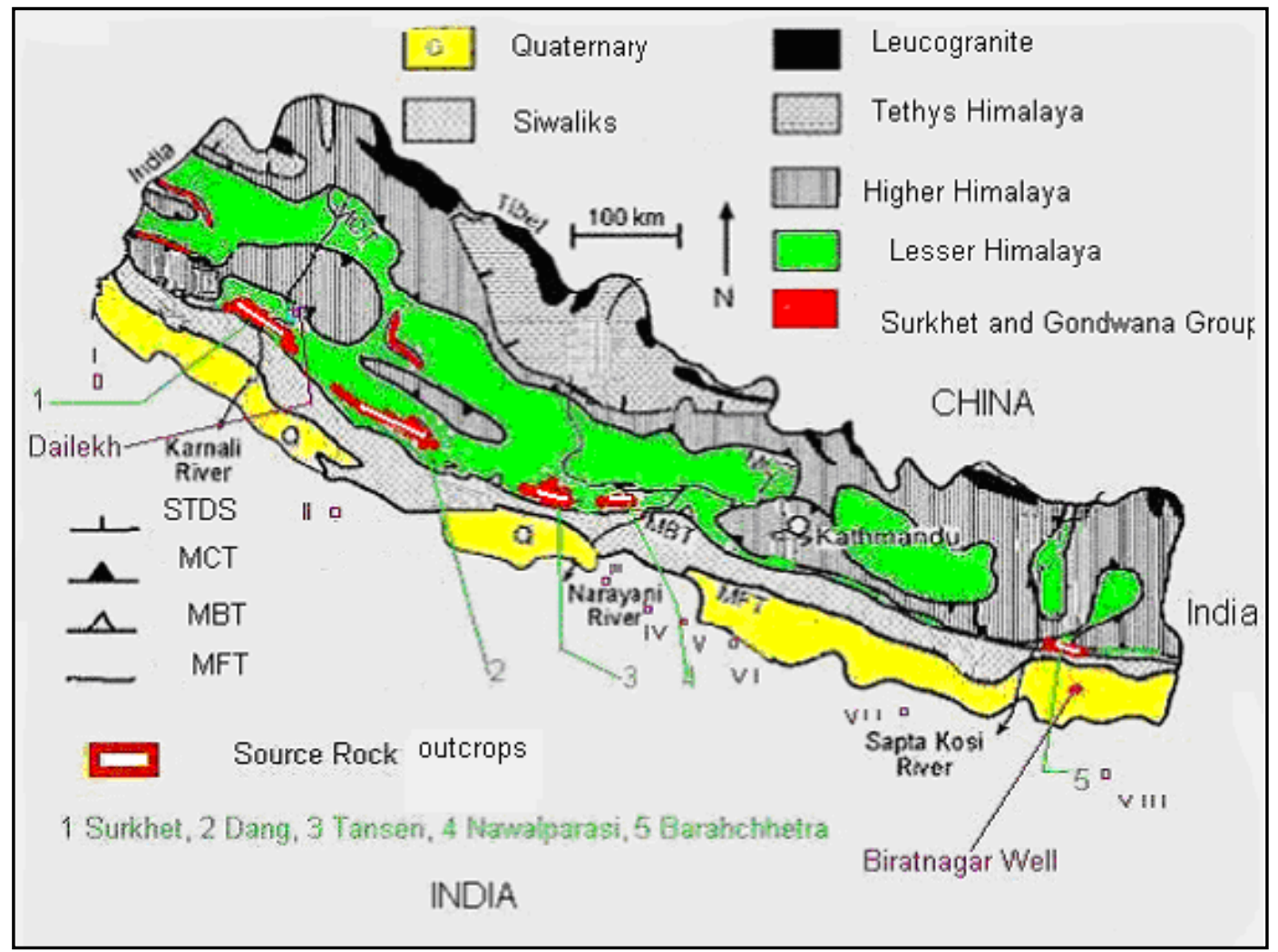

Fig. 2 Geological map of Nepal showing the main structural elements (STDS: South Tibetan Detachment System, MCT: Main Central Thrust, MBT: Main Boundary Thrust, MFT: Main frontal thrust and locations of Indian wells, some of which have HC shows.) Note that source rock outcrops (1-5) are in the hanging wall of the MBT. Well locations in the Indian part of the Basin: I Puranpur, II Matera (gas and oil show), III Ganauli (oil show), IV Kadmaha (oil show), V Gandak, VI Raxual, VII Madhubani (oil and gas show), VIII Purnea. 


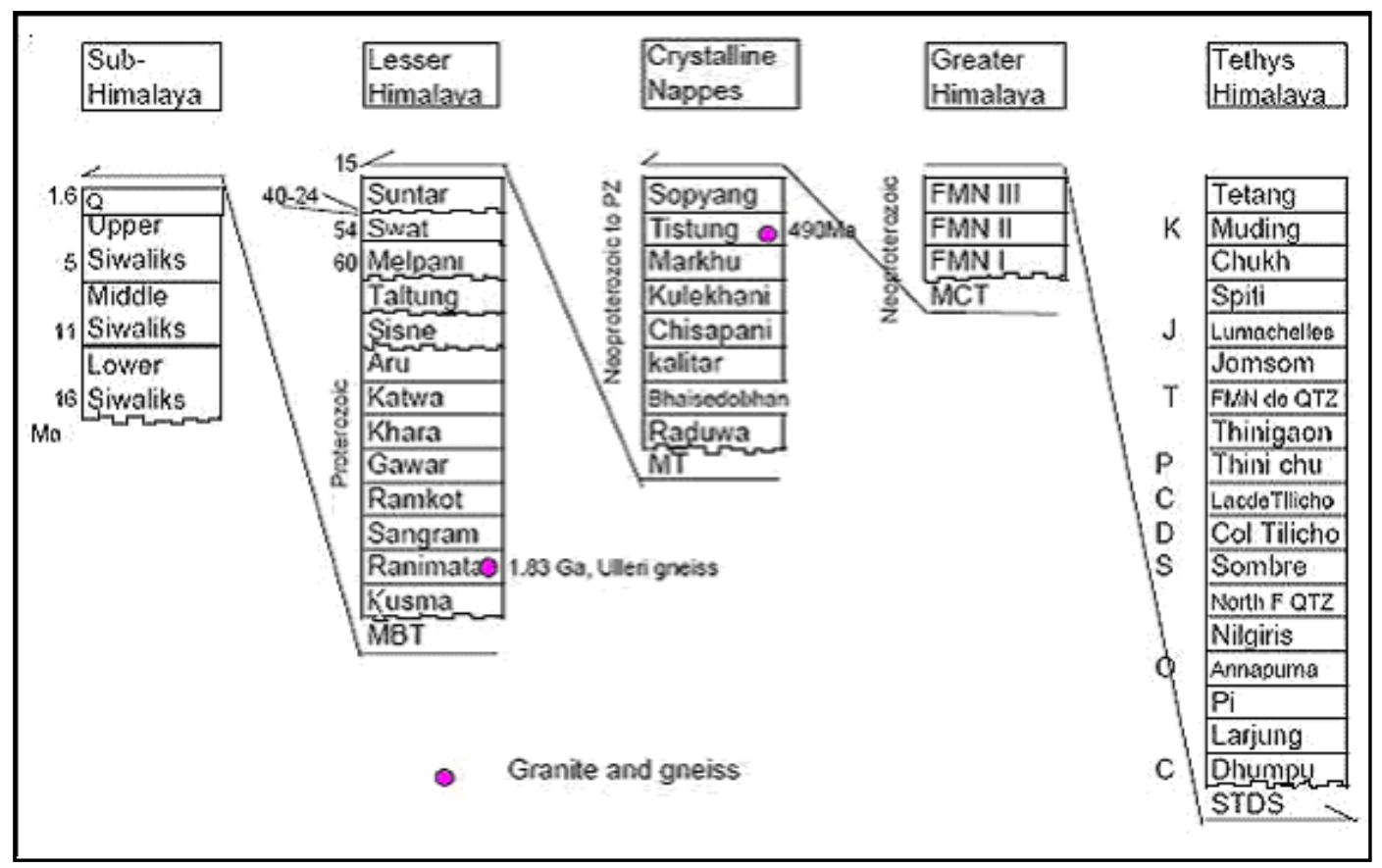

Fig. 3 Stratigraphic units of the Himalayan domain and their position in a tectonic environment in Nepal. Ages of the units in Ma are shown for the Sub-Himalaya and Lesser Himalaya columns. Radiometric ages are shown by dots. Geological Periods: C-Cambrian, O-Ordovician, S-Silurian, D-Devonian, C-Carboniferous, P-Permian, T-Triassic, J-Jurassic, K-Cretaceous shown on the Tethys Himalayan column.

along the STDS (South Tibetan Detachment System). One of the units, the Late Jurassic-Spiti dark fossiliferous shales, a potential hydrocarbon source rock in the Himalayan region, is overmature with an average vitrinite reflectance of $1.8 \%$ in Thakkhola area. They have a thickness of more than $250 \mathrm{~m}$.

The Lesser Himalayan zone lies between the MBT to the south and MCT in the north. The late Precambrian to Cambrian low grade metamorphic rocks is unconformably overlain by clastics and is covered by late Cretaceous to Eocene carbonates and clastics. They are overridden by crystalline nappes and klippen in some places. The Lesser Himalayan sedimentary rocks are divided into the Lower Lesser Himalayan Sequence and the Upper Lesser Himalayan Sequence.

The Lower Lesser Himalayan Sequence is represented by Dailekh Group [2, 3]. The Dailekh Group consists of the Kusma and the Ranimata Formations. These consist of green gray chloritic phyllite, gritty phyllite and white gray quartzites with amphibolite dykes. The only known age of the Ulleri augen gneiss is $1.83 \mathrm{Ga}$. Proterozoic associated with the Ranimata Formation. The rocks of the Dailekh Group are not considered to be hydrocarbon exploration objectives. The Upper Lesser Himalayan Sequence is represented by the Lakharpata Group of late Proterozoic to early Paleozoic age. It is followed by an unconformably overlying continental series of Gondwana sedimentary rocks of Permo-Carboniferous to Lower Cretaceous age. The Gondwana rocks are unconformably overlain by the Surkhet Group of rocks of Upper Cretaceous to Lower Miocene age.

Lakharpata Group consists of the Sangram, Ramkot, Gawar, Khara, Katwa and Aru Formations. They are Precambrian to early Paleozoic age. This is also named as upper part of the Midland Supergroup. This group and its Vindhyan equivalent are an important exploration objective. Gondwana Group rocks are discontinuously exposed along the outer Lesser Himalaya of Nepal. The Late Carboniferous to Permian Sisne Formation consists of tillites and intercalated shale. The late Jurassic to early Cretaceous Taltung Formation consists of conglomerate beds and black shale. The Gondwana Group has an exploration 
potential for hydrocarbons, both as potential source and reservoir rocks.

The Surkhet Group sediments largely crop out in the western Upper Lesser Himalayas [1], but also occur in the central part. They unconformably overlie the Lakharpata or Gondwana rocks and include the Melpani (Late Cretaceous-Paleocene), Swat (Eocene) and Suntar (Oligocene to Early Miocene) Formations. The group attains a maximum thickness of 1,200 m. The group is correlated with the oil and gas producing formations of the Assam and Potwar basins.

The Siwalik Group in Nepal is exposed in the southern frontal area of the Himalaya of Nepal. It is bounded by the MFT (main frontal trust) to the south and the MBT (main boundary thrust) to the north. Since the middle Miocene, about $6 \mathrm{~km}$ thick sediments, consisting of fluvial mudstone, sandstone, and conglomerate, have been formed in the Indo-Gangetic foreland basin. Lithostratigraphy [4-6] and magnetostratigraphy [7-9] has been established. Refs. [2] and [10] compiled and gave five-fold lithostratigraphic subdivisions of the Siwaliks. The Siwaliks in Nepal Himalaya can be divided into Lower, Middle and Upper Units. The middle unit is divided into lower middle and upper middle Siwaliks, whereas the Upper Siwalik is divided into lower upper and upper upper siwaliks. Their age ranges from Middle Miocene to Lower Pleistocene.

Some Lower Siwalik shales have shown hydrocarbon shows in some of the Indian wells. The Lower Siwalik shales are expected to be seals. The Middle Siwalik sandstones have the potential for reservoir rocks. Exterior Foothill Belt (Terai) zone represents the northern edge of the vast alluvial Indo-Gangetic foreland basin. In the north it is bounded by the MFT. Terai (Pleistocene-Recent) rests on the Siwalik Group. A number of thrusts and thrust propagated folds have been recognized in Siwaliks [11]. The Recent Terai sediments represent the latest foreland basin deposits of the Himalaya, their precursors being the Neogene Siwaliks and the still older Late Oligocene-Early Miocene Dumri Formation, which has been tectonically incorporated into the Lesser Himalaya [12].

The computed thermal structure of the Indian plate away from the Himalaya implies a surface heat flow with $60 \mathrm{~mW} \cdot \mathrm{m}^{-2}$ in the cratonic areas of Northern India [13].

The Siwalik imbrication starts from 4.1 to $1.8 \mathrm{Ma}$ with the MBT and MFT active in Pliocene to recent time. The timing of Siwalik thrusts [14] is possibly 2.4 to $1.8 \mathrm{Ma}$ for the MFT and 3 to $2.4 \mathrm{Ma}$ for the MDT.

The ages from magnetostratigraphy of the Siwalik Group show variations from west to east in Nepal. The geological age ranges from 16 Ma (Karnali section, west) to 2.5 Ma (Rato khola section, east) [15]. Reflection seismic data indicate that the locus of the active shortening along the thrust front of the thrust belt is in the subsurface beneath the northern Indo-Gangatic plain and a regional decollement exists in the Lower Siwalik rocks at a depth of 5-6 km in Nepal.

\section{Petroleum Geology of Exploration Block 2}

The stratigraphy of Exploration Block 2 is based on the surface geological mapping of the area and also the subsurface geological information based on the seismic data.

\subsection{Dailekh Group (Precambrian)}

The Dailekh Group is represented by the Dubbidanda Formation in the studied area. It is well exposed to the north of the RMT (Ranimata Thrust). The hanging wall of the RMT is well exposed in the northern part of Exploration Block 2. The Dubbidanda Formation is thrusted over the Suntar Formation of the Surkhet Group (Fig. 4).

The Dubbidanda Formation (Dhb) is well exposed along the course of the Karnali River and Seti Ganga. It also makes a klippe in the Bada area. It is represented by gray, green gray chloritic phyllite, gritty phyllite and white gray quartzites with amphibolite dykes. The thickness is considered to be $2,000+\mathrm{m}$. 


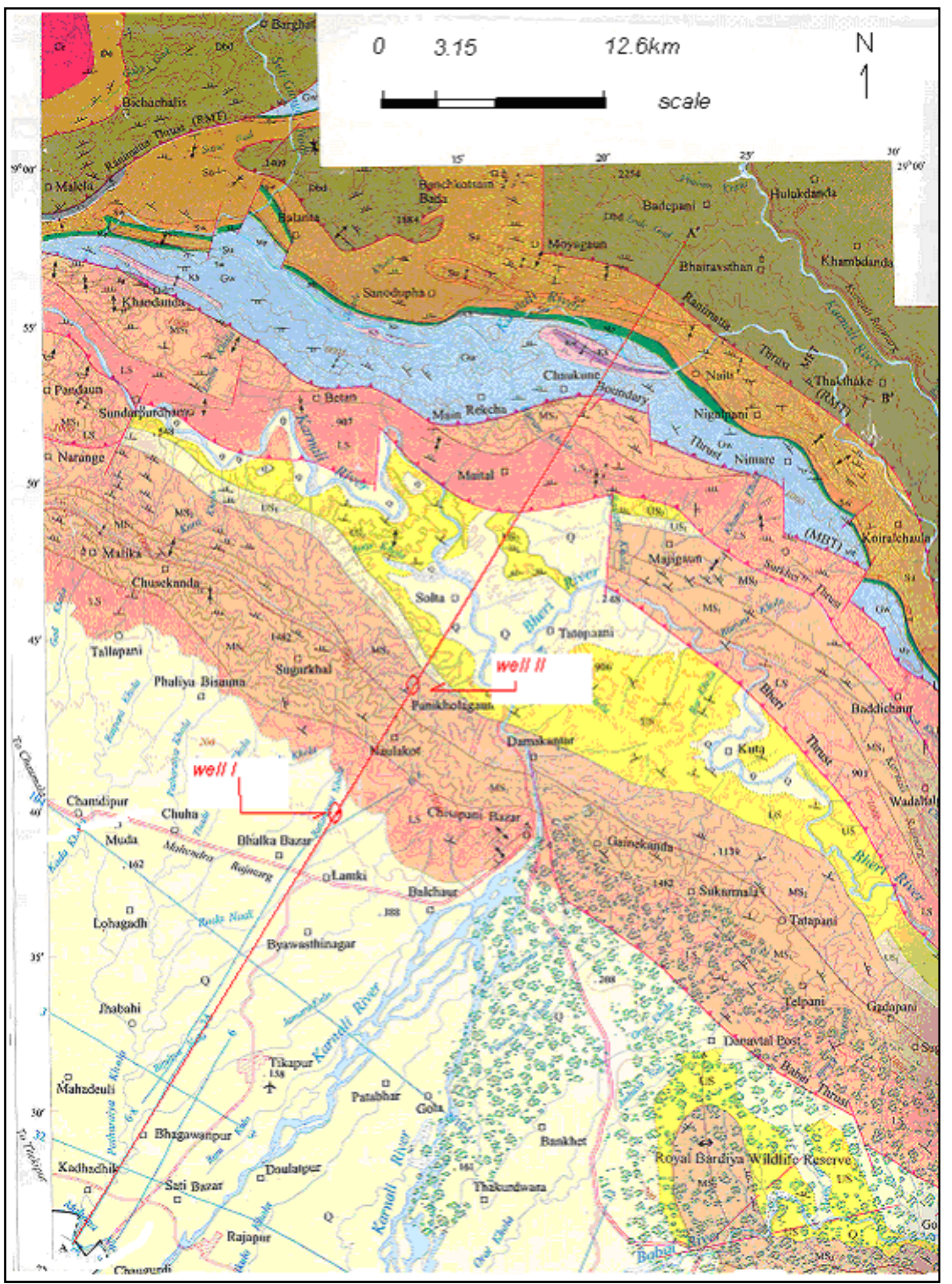

Fig. 4 General geological map of Petroleum Exploration Block 2, Karnali, western Nepal [2]. AA' is the location of the cross section. Wells I and II represent synthetic well locations in the exterior belt (Terai) and Siwalik fold and thrust belt respectively. 
The Dailekh oil and gas seeps in the Dailekh region of western Nepal are within this formation. The analytical results of these oil and several gas samples indicated that this oil and gas has a thermogenic origin from a mature source rock. Chromatograms suggest that the oil samples represent light (mature) oil that has been severely biodegraded.

\subsection{Lakharpata Group (Precambrian to Early Palaeozoic)}

The Lakharpata Group consists of five formations (Fig. 3). They are cropping out in the hanging-wall of the MBT.

The Sangram Formation is exposed in a very narrow zone in the northern part of the Khandanda area in the NW portion of Exploration Block 2 in which it rests on the hanging-wall of MBT which separates it from Lower Middle Siwalik (MS1) on the footwall. It consists of greenish gray to gray carbonaceous shale. The Sangram Formation has good source rock (TOC 7-9\%) potential. The Ramkot Formation overlies the Sangram Formation and is exposed in a narrow zone in the northern part of the Khandanda area. It consists of pink sandstone with ripple marks and purple and gray shale. Mud cracks can be seen at some places.

The Gawar Formation consists of stromatolitic dolomites, limestone with white gray subordinate sandstone and shale. The thickness of the formation is about 2,500 $\mathrm{m}$ in this area. It has also source and reservoir rock potential.

The Khara Formation is found as isolated patches of erosional remanents in the core of the synclines surrounded by stromatolitic dolomites of the Gawar Formation. The synclinal exposures are found in three different parts in the hanging-wall of the MBT (Fig. 3). It is represented by green, gray and purple shale and limestone. The thickness of the formation is about $250 \mathrm{~m}$.

The Katuwa Formation is also cropping out in the core of a syncline to the north of the Chaukune area. It consists of gray to dark gray shale with limestone dominant in the upper part. The thickness in this area is about $100 \mathrm{~m}$. It has also source rock potential.

\subsection{Gondwana Group (Carboniferous to Lower Cretaceous)}

The Gondwana Group is represented by the Charchare Formation which is cropping out in two small patches near the southern areas of Sanodupha and Malela in the northern part of Exploration Block 2 (Fig. 3). It consists of gray, dark gray shale, calcareous shale and diamictite with conglomerate beds. The equivalent lower coal bearing Sisne Formation in west Nepal has both source and reservoir potential for gas and the upper marine sediments are a potential oil source rock with a reported TOC of about $10 \%$.

\subsection{Surkhet Group (Upper Cretaceous to Lower Miocene)}

The Surkhet Group is exposed to the northern parts of the MBT in the Lesser Himalaya. It consists of Melpani, Swat and Suntar Formations. The best exposures are found along the Karnali River near Naiti (Fig. 4). The Surkhet Group contains potential reservoir, source and seal rocks. The Swat Formation shales have Type II kerogen associated with a limited percentage of Type III. The Surkhet Group in the subsurface is interpreted as lateral equivalent of the "Unnamed Formation" (Palaeogene) that occurs in the northern Indian wells close to the Nepal border.

The Melpani Formation consists of white, gray, ferruginous quartzitic sandstone and gray to dark gray shale with basal conglomerate. Coaly materials and bivalves are present in some of the outcrops. The exposed thickness of the formation is about $300 \mathrm{~m}$. Potential reservoir rocks are developed in this formation and solid hydrocarbons have in places filled the porosity of the sandstones. The sandstones have $7-10 \%$ porosity. These are correlated with the oil and gas producing formations of the Assam and Potwar Basins. Interbedded sandstones of Kopili Formation and carbonates of Sylhet Formation are the reservoirs 
in Assam, where permeability ranges from $8 \mathrm{mD}$ to as high as $800 \mathrm{mD}$ in the Tipam Group [16]. Porosity ranges from less than $7 \%$ to $30 \%$. The Paleocene Namal and Eocene Ghazij Formations have porosities of 9-30\%, with average 12-16\% in Potwar [17].

The Swat Formation consists of about 200 m thick gray to dark gray shale with foraminiferal limestone and coquina exposed to the north of Sanodhupa, Naiti and Syaule Khola areas. This formation occurs from NW to SE in the hanging-wall of the MBT in the northern part of Exploration Block 2. It contains potential source (TOC $>2 \%$ ) and seal rocks.

The Suntar Formation is the youngest formation in the hanging-wall of the MBT system. The exposures are restricted to the northern part of Exploration Block 2 around Sanodhupa, Sisnegad, Naiti, Koiralchaula and Upallo Syaule. It consists of green and greenish gray sandstone and purple shale with occasional marl. The exposed thickness of the formation is about $1,000 \mathrm{~m}$. It also has some reservoir potential.

Subsurface geological sections based on the seismic interpretation of the western Terai reveal the presence of Surkhet Group in the tectonic wedges as well as in the undeformed Terai belt beneath the Lower Siwaliks (Fig. 4).

\subsection{Siwalik Group (Middle Miocene to Lower Pleistocene)}

The base of the Siwalik Group is not exposed in this section and top of the group is truncated by a thrust fault. The upheaval of the Higher Himalaya in the north brought about the downwarped Siwalik Basin in the foreland to the south of the Lesser Himalaya. The Siwalik Basin is now represented low hilly mountainous range. It is delineated by the HFT (Himalayan frontal thrust) and MBT (main boundary thrust) to the south and north respectively forming imbricated fault propagation folds. This group is divided into Lower Siwalik, Lower Middle Siwalik, Upper Middle Siwalik, Lower Upper Siwalik and Upper Upper Siwalik Formations in Exploration Block
2 (Fig. 4). There are effective potential sandstone reservoirs in the Siwaliks.

The Lower Siwalik is the oldest formation but the base is not exposed anywhere. The top is conformable with the Lower Middle Siwalik Formation. It is exposed as a southernmost boundary of the Himalaya on the hanging-wall of the HFT. It is repeated in the imbricate slices in the Siwalik ranges. It is best exposed in the Chisapani area of Karnali River. The exposed thickness is about $1,500 \mathrm{~m}$. It consists of fine grained sandstone with interbeds of purple or red coloured mudstone, shale, siltstone and occasional marl beds. The abundant shale in the Lower Siwaliks has potential sealing capacity. Hydrocarbon has been shown by some of the Indian well data in this formation.

The Middle Siwalik unit is divided into two lithological units: Lower Middle Siwalik and Upper Middle Siwalik. The 1,500 m thick Lower Middle Siwalik unit consists of medium, fine to medium grained sandstones with interbeds of siltstones and mudstones. Coaly materials and plant fossils are present in some places. The 1,250 $\mathrm{m}$ thick Upper Middle Siwalik consists of medium to coarse grained sandstones, pebbly sandstones with siltstones and mudstones with relics of hard sandstones. It is best exposed along the Bheri and Karnali River near Panikhola gaon (Village in Nepali) and Damakantar. The thick sandstone units have reservoir potential.

The Upper Siwalik unit is also divided into two lithological units: Lower Upper Siwalik and Upper Upper Siwalik. The 700 m thick Lower Upper Siwalik is represented by pebbly conglomerates, yellow and gray mudstones with minor gray sandstones which are exposed to the northwest of Panikholagaon, north of Majigaon, and north of Gadapani. The Upper Upper Siwalik is about $750 \mathrm{~m}$ thick and consists of boulder and cobble conglomerates with minor yellow, gray mudstones and siltstones, and also sandstone bands and lenses in the conglomerates. It crops out along the Bheri River section in the Tatopani area which covers a large portion of the central sector of 
Exploration Block 2.

Subsurface sections based on seismic interpretation were used to reconstruct the subsurface geology which reveals the slight inclination and thicknesses increase of the Siwalik beds towards the hinterland. A series of imbricate stacks are found in the Siwalik domain. The base Siwalik unconformity was depicted on the cross section by the use of seismic data (Fig. 4).

\subsection{Surfacial Deposits: (Quaternary to Recent)}

The Karnali and Bheri River alluvium and Terai plain are covered by surfacial Quaternary deposits. They consist of boulder, gravel, sand and clay in varying proportions. The thickness is about $200 \mathrm{~m}$ to $450 \mathrm{~m}$.

\section{Basin Modelling Exterior Terai Belt}

Basin modelling aims at reconstructing the evolution of a sedimentary basin in order to make quantitative predictions leading to hydrocarbon generation, migration and accumulation. Factors to be taken into account include: porous medium compaction, heat transfer, hydrocarbon generation and fluid flow. A 1D basin modelling approach is satisfactory to simulate the temperature evolution and the maturation of organic matter as the thermal transfer is mostly vertical. 2D models provide the possibilities of performing an evaluation of the pressure history and appreciating the hydrocarbon migration and reservoir filling. However, these evaluations can only be qualitative because fluid (water, oil and gas) migration is mainly convective and therefore sensitive to the 3D geometry and anisotropy of a basin. The sedimentary 1D basin model is able to handle relatively simple geometries resulting from deposition, erosion and vertical compaction. However, exploration in fold and thrust belt needs models which handle faulting. In this context, the Siwalik foreland basin of Nepal is modeled using BasinMod 1D software which has capability to handle simple geometry as well as faulting. Two case studies based on the simple geometry of the Exterior belt (Terai) and geometry with faulting in the Siwalik fold and thrust belt are performed.

\subsection{Parameterization}

A 2D geoseismic section has been used to locate and produce two synthetic wells as shown in Fig. 5. Based on these wells, all stratigraphic parameters are extracted.

The lithological units in the wells and their present thicknesses are derived from the section. The stratigraphic age for each unit is derived $[18,19]$. The initial porosity and compaction factors are used as default values and value for each respective lithological unit is derived thereafter. The matrix density is set for sandstone $2.65 \mathrm{~g} / \mathrm{cm}^{3}$, siltstone 2.67 $\mathrm{g} / \mathrm{cm}^{3}$ and shale $2.7 \mathrm{~g} / \mathrm{cm}^{3}$. The matrix thermal conductivity for sandstone is set to $4.2 \mathrm{~W} / \mathrm{m} \cdot{ }^{\circ} \mathrm{C}$ and other values for lithologies are used as default parameters. Other input parameters are discussed in the

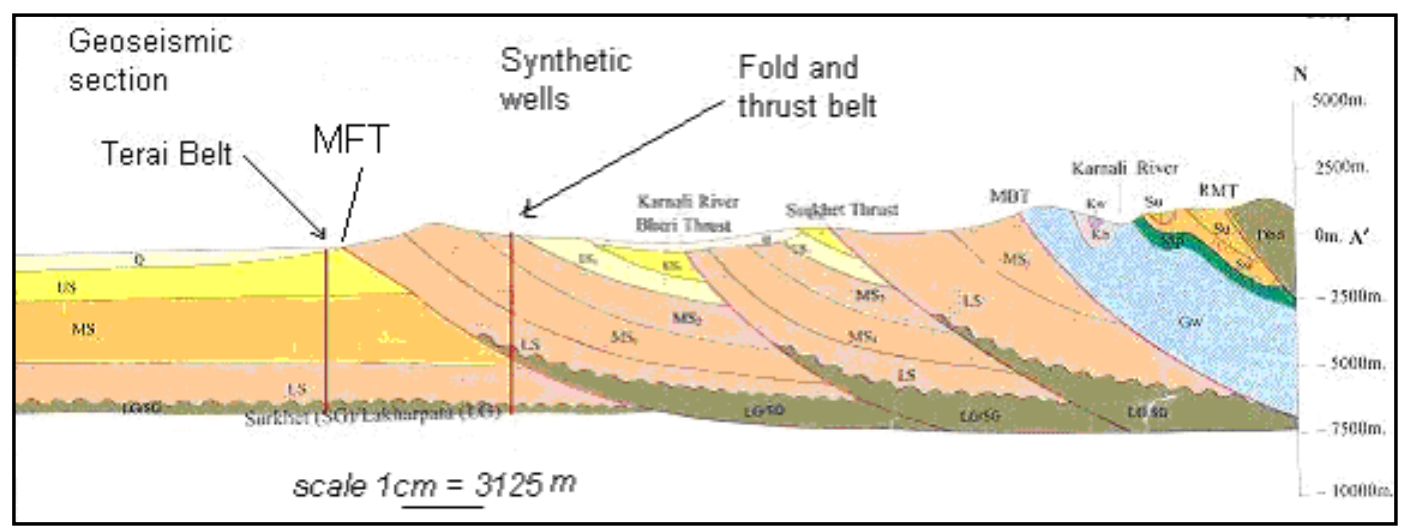

Fig. 5 Location of the two synthetic wells: Exterior Belt (Terai) and Siwalik fold and thrust belt, Exploration Block 2. 
subsequent sections.

\section{Case Study I: Exterior Belt (Terai)}

\subsection{Burial History}

The burial history is the model of stratigraphy versus time utilizing a wide range of parameters. Geohistory uses sea levels and sea depths with which we can implement Vail-type changes through time.

Burial history models are not geologically as realistic as geohistory models but they usually suffice in most situations. The stratigraphic data entry process is based on the synthetic well data of exterior belt (Terai). Formations and events, such as hiatuses, are all entered as discrete stratigraphic units into a master spreadsheet of Stratigraphy (Appendix 1a), using thicknesses. A beginning age is set for each event. Rock properties are entered for stratigraphic units (Appendix 1b and 1c). Calculations are performed on individual units rather than averaged over the section. When plotting geohistory diagrams, stratigraphic units are plotted sequentially as discrete beds. This approach allows accurate decompaction and subsequent backstripping.

BasinMod 1D contains a lithology library. The library contains a default set of eight pure lithologies (Appendix 1b) along with the rock property values which BasinMod requires for its calculations. The library also contains three variable, user-defined lithologies which can be incorporated into user-created lithology mixes. Lithology Mixes option is used to create mixed lithologies by specifying percentages of the pure lithologic components as well as user-defined lithologies. The rock properties for the lithology mixes are interpolated from the values for the pure and user defined lithologies. The user defined lithology is set for conglomerates of the Upper Siwalik.

The calculated rock properties for all lithologies are summarized in the Mixed Lithology Parameters table
(Appendix 1c). Once completed, this lithology library can be used in the BasinMod 1D mod files to minimize data re-entry and finished up with final model drawings.

\subsection{Model Inputs}

- All depth parameters are set into meters;

- Present day surface temperature is set to $25{ }^{\circ} \mathrm{C}$ (Appendix 1d);

- Sea level and sea depth parameters with time are assumed as set in the Standard Vail type curves (Appendix 1d);

- The values of calculated initial porosity (10\%) are set only for the Melpani Formation sandstones. The measured 2\% TOC is set for the Swat Formation dark shales;

- The Surkhet Group is divided into the Suntar, Swat and Melpani Formations.

The geohistory curves (Fig. 6) are a result of the input parameters. They also show rapid sedimentation and tectonic subsidence as a result of the additional weight of tectonic loads of folds and thrust belts causing the Indian lithosphere to sink.

\subsection{Maturity}

Vitrinite reflectance (\%Ro) is the reflectance of vitrinite particles that occur in organic matter deposited in sediments derived from higher plants. $\%$ Ro is extensively used worldwide in the assessment of composition of a kerogen. The LLNL (Lawrence Livermore National Laboratory) calculates vitrinite composition from a chemical kinetic model that considers separate reactions for the elimination of $\mathrm{H}_{2} \mathrm{O}, \mathrm{CO}_{2}, \mathrm{CH}_{4}$, and higher $\mathrm{HC}$ from the structure. The program then calculates reflectance from correlations of \%Ro with carbon content and with H/C and $\mathrm{O} / \mathrm{C}$ ratios.

The modeled value for \%Ro of the Surkhet Group Top $(5,777 \mathrm{~m})$ is 0.86 and Bottom $(6,164 \mathrm{~m})$ is 0.94 (Fig. 8). This implies that the Surkhet Group lies in 


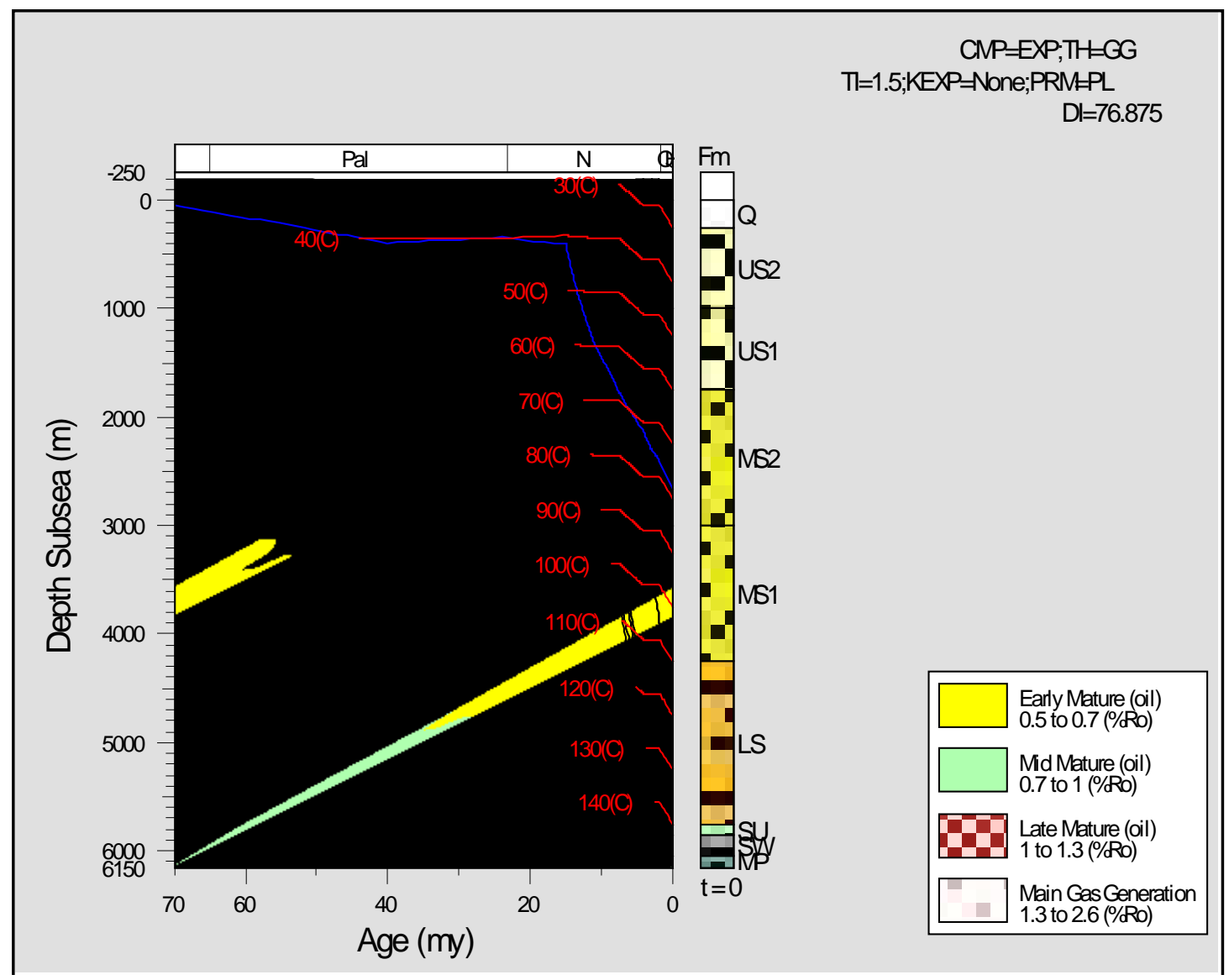

Fig. 6 Burial history curves for the exterior belt (Terai), Exploration Block 2. Isotherms are in red, blue is tectonic subsidence curve and stratigraphic trajectories corresponding to lithological column. Legend in inset indicates the maturity windows. Quaternary (Q), Upper Upper Siwalik (US2), Lower Upper Siwalik (US1), Upper Middle Siwalik (MS2), Lower Middle SIwalik (MS1), Lower Siwalik (LS), Suntar Formation (SU), Swat Formation (SW), Melpani Formation (MP).

the mid mature oil window in this well.

\subsection{Geothermal Gradient}

The geothermal gradient is set to $20^{\circ} \mathrm{C} / \mathrm{km}$ since some of the Indian wells in the Indo-Gangetic plain have the same geothermal gradient. The modeled value for depth of $6,013 \mathrm{~m}$ is $145^{\circ} \mathrm{C}$ for the Swat Formation (Fig. 7). The thermal history is calculated according to this value. This gradient calculation method does not take lithology into account when calculating temperature history. The burial history curve (Fig. 6) is plotted with isotherms which are of constant slope regardless of lithology. The assumption is that there has been no change of gradient with time so that the paleo-gradient will be calculated linearly from the region surrounding the load (Fig. 6). The maturity variation with respect to depth are also important. single value entered. The paleo-geothermal gradient is lithosphere responds flexurally, the subsidence occurs not only immediately underneath the load but in broad causing the Indian lithosphere to sink. Because the combined with paleo-surface temperatures to calculate thermal history for all times and depths. The temperature is calculated using the interpolated surface temperature and gradient profile. When using gradients, thermal history is independent of burial history. Therefore the gradient method usually gives different results than the heat flow method, which is dependent upon burial history.

\subsection{Porosity}

Porosity is assumed to be a function of depth. If the 


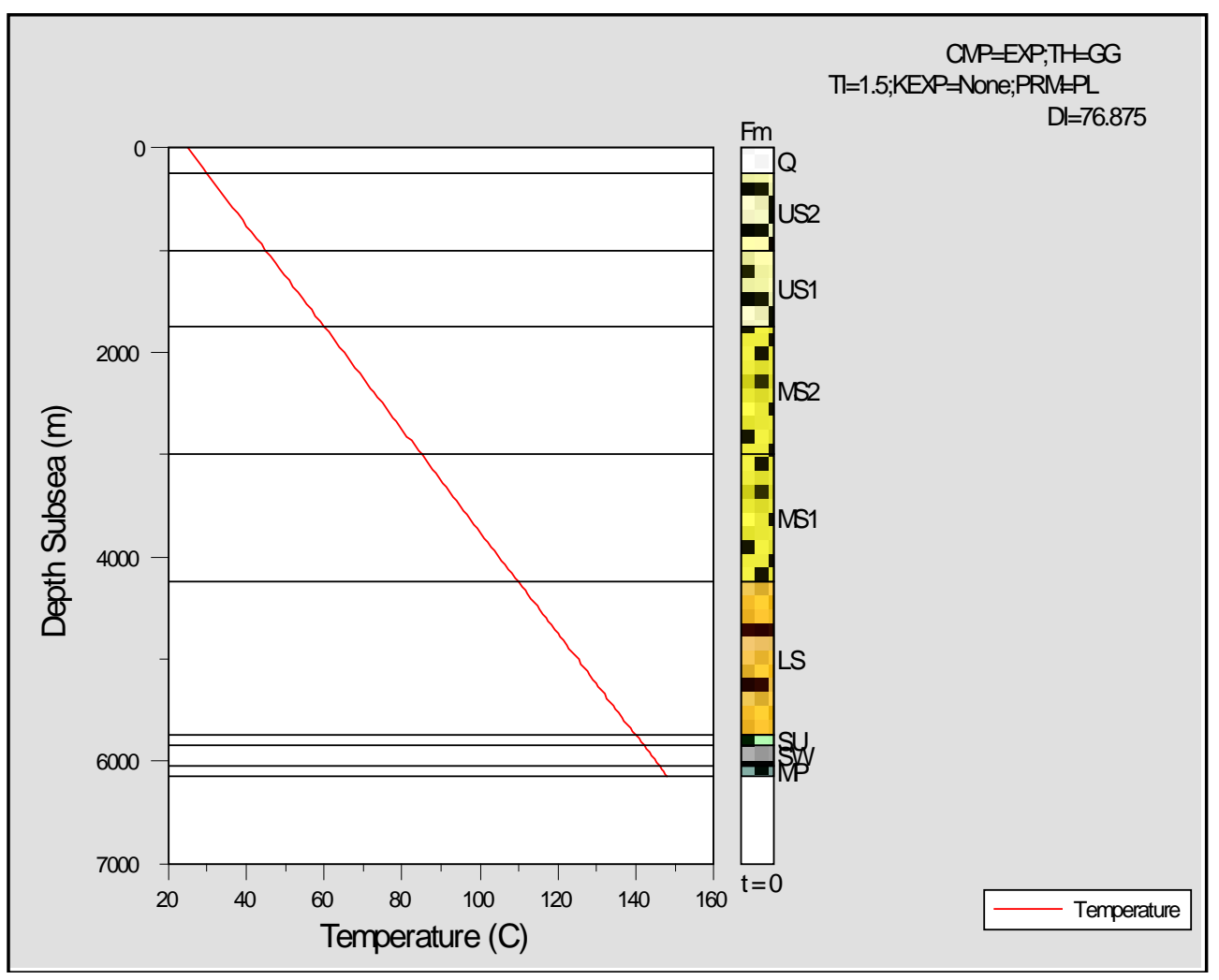

Fig.7 Geothermal gradient, exterior belt (Terai), Exploration Block 2.

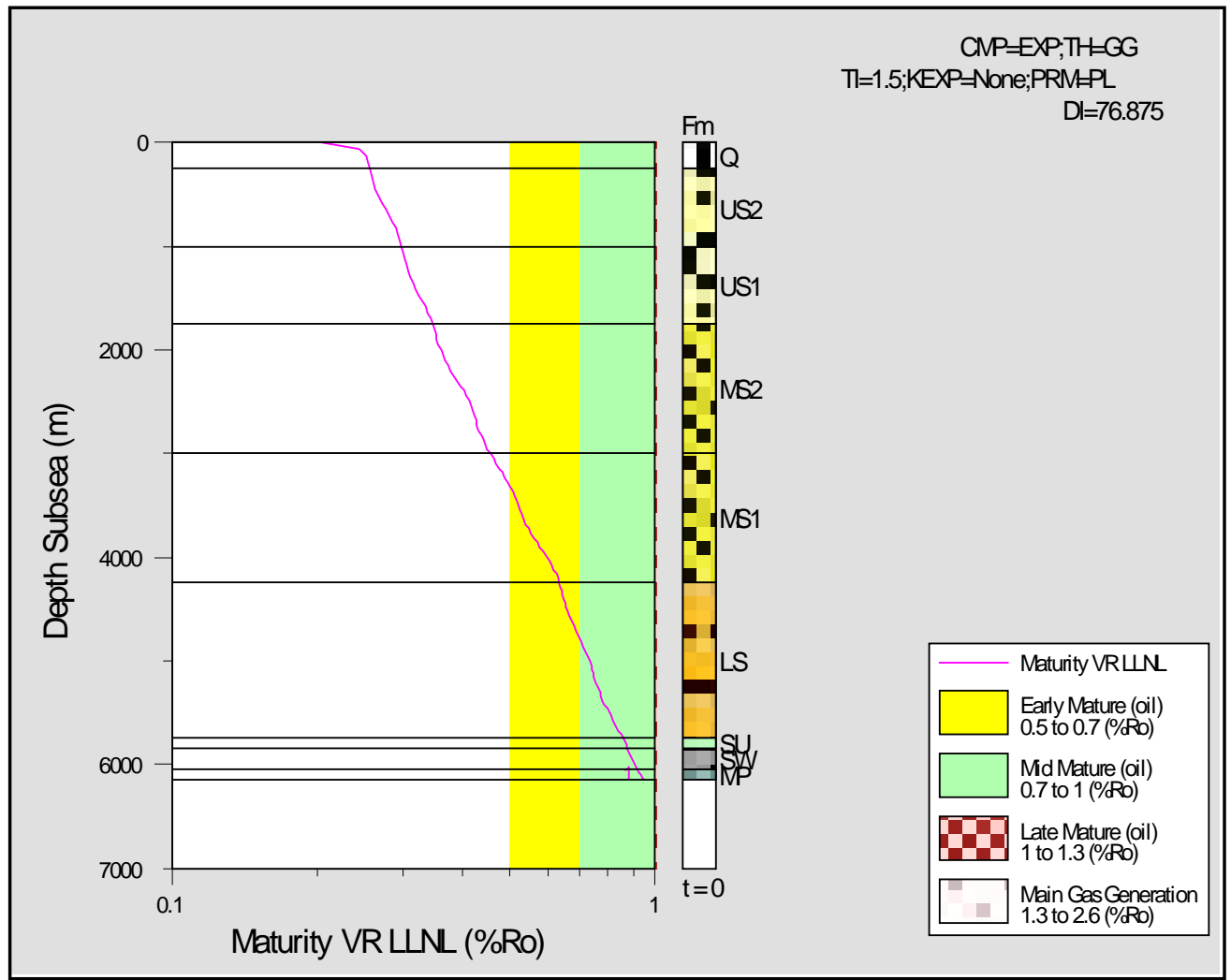

Fig. 8 Maturity windows for the synthetic well from Exterior belt (Terai), Exploration Block 2. 
geothermal gradient is used in thermal modeling, the compaction is said to have no effect on down-hole temperatures. Compaction mainly occurs as a result of loading (mechanical compaction) although many associated phenomena can complicate the process; such as overpressuring, cementation and diagenesis.

The porosity at the time of deposition is initial porosity. The initial porosity is used as default values. The measured porosity (10\%) is set for the Melpani Formation sandstones of the Surkhet Group. The modeled porosities for the Suntar Formation (0.0693 at $5,793 \mathrm{~m})$, the Swat Formation (0.045 at 5,920 $\mathrm{m}$ ) and the Melpani Formation (0.09 at 6,097 m) of the Surkhet Group. Similarly, the Lower Siwalik (Top 0.09, 4,259 $\mathrm{m}$ ) and (Bottom 0.05, 5,760 m), the Lower Middle Siwalik (MS1) (Top 0.175, 3,010.69 m) and (Bottom $0.11,4,241 \mathrm{~m}$ ), the Upper Middle Siwalik (MS2) (Top 0.17, 2,994 m) and (Bottom 0.27, 1,796 m), the Upper Siwalik (Top 0.43, $278 \mathrm{~m}$ ) and ( Bottom 0.27, 1,745 m) and the Quaternary sediments (Top 0.48) are the model porosities (Fig. 9).

\subsection{Oil Generation Rate}

The burial history curves are drawn based on oil generation rate /TOC. The oil generation for the top of the Swat Formation starts at 5.66 Ma at 3,996 m depth to present at $5,850 \mathrm{~m}$ depth and in the bottom at 6.34 Ma at 3,988 $\mathrm{m}$ depth is to present at 6,050 $\mathrm{m}$ depth. The peak oil generation period modeled for the Swat Formation bottom is 2.44-1.32 Ma at 5,435-5,782 m depth (Fig. 10).

\subsection{Cumulative Hydrocarbon}

The cumulative hydrocarbon in exterior belt (Terai) based on synthetic well has about $360 \mathrm{mg} / \mathrm{g}$ TOC assuming the Swat Formation black shales as source rocks (Fig. 11). The source rock maturity model shows the mid-mature oil window for the Swat Formation at around $6 \mathrm{~km}$ depth. The oil generation is still continuing at the present day.

\subsection{Sedimentation Rate}

Sediment accumulation is strongly controlled by changes in sea level, tectonic subsidence rates, and climatic effects on the production of sediment. The sedimentation rates as revealed from the synthetic well in Exterior belt (Terai) are shown in Fig. 12. The age ranges and respective sedimentation rates derived from Fig. 12 for the period 15-1.8 Ma, when the sedimentation rates were high, are presented in Table 1.

\subsection{Petroleum System}

To facilitate discussion of petroleum generation in Exploration Block 2, a petroleum system chart includes geologic elements and processes that are essential for an oil and gas deposit to exist. These basic elements include source rock, maturation, reservoir rock, trap, and seal. The Swat Formation black shales of the Surkhet Group are source rocks consisting of more than 2\% TOC. The Melpani Formation sandstones of the Surkhet Group, with surface porosities of $7-10 \%$, are potential reservoir rocks, as are also possibly the Lower and Middle Siwalik sandstones. The modeled porosity trends showing that the Middle Siwalik sandstones are also the potential reservoirs (Fig. 9). The mid mature oil window (Fig. 8) lies in the Surkhet Group and the oil generation rate (Fig. 10) models the peak oil generation for the top of the Swat Formation at 2.44-1.32 Ma at 5,435-5,782 $\mathrm{m}$ depth which also coincides the time window of peak oil generation for top and bottom of the Swat Formation (Fig. 13). The time to early oil generation for top and bottom of the Swat Formation is about 3.5 Ma and 4.5 Ma respectively (Fig. 13). The likely time of thrusting of the MFT and MDT (the Bheri and the Surkhet Thrusts in between the MFT and the MBT (Fig. 4), are the laterally relayed thrusts of Main Dun Thrust (MDT) in west Nepal) are 2.4-1.8 Ma and 3-2.4 Ma respectively. The Lower Siwalik shales are less porous compared with the underlying Surkhet Group. These thick shale 


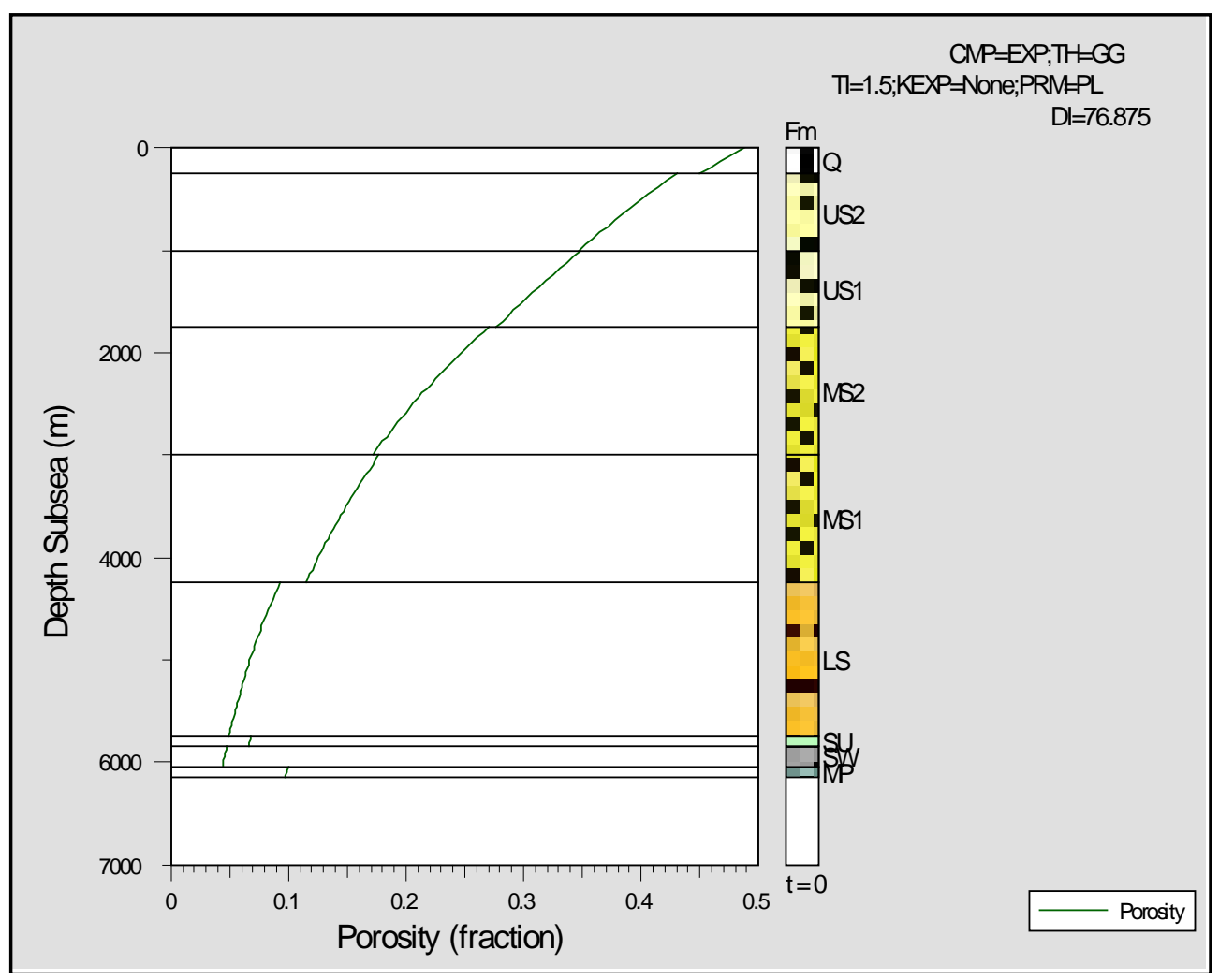

Fig. 9 Porosity model for the exterior belt (Terai), Exploration Block 2.

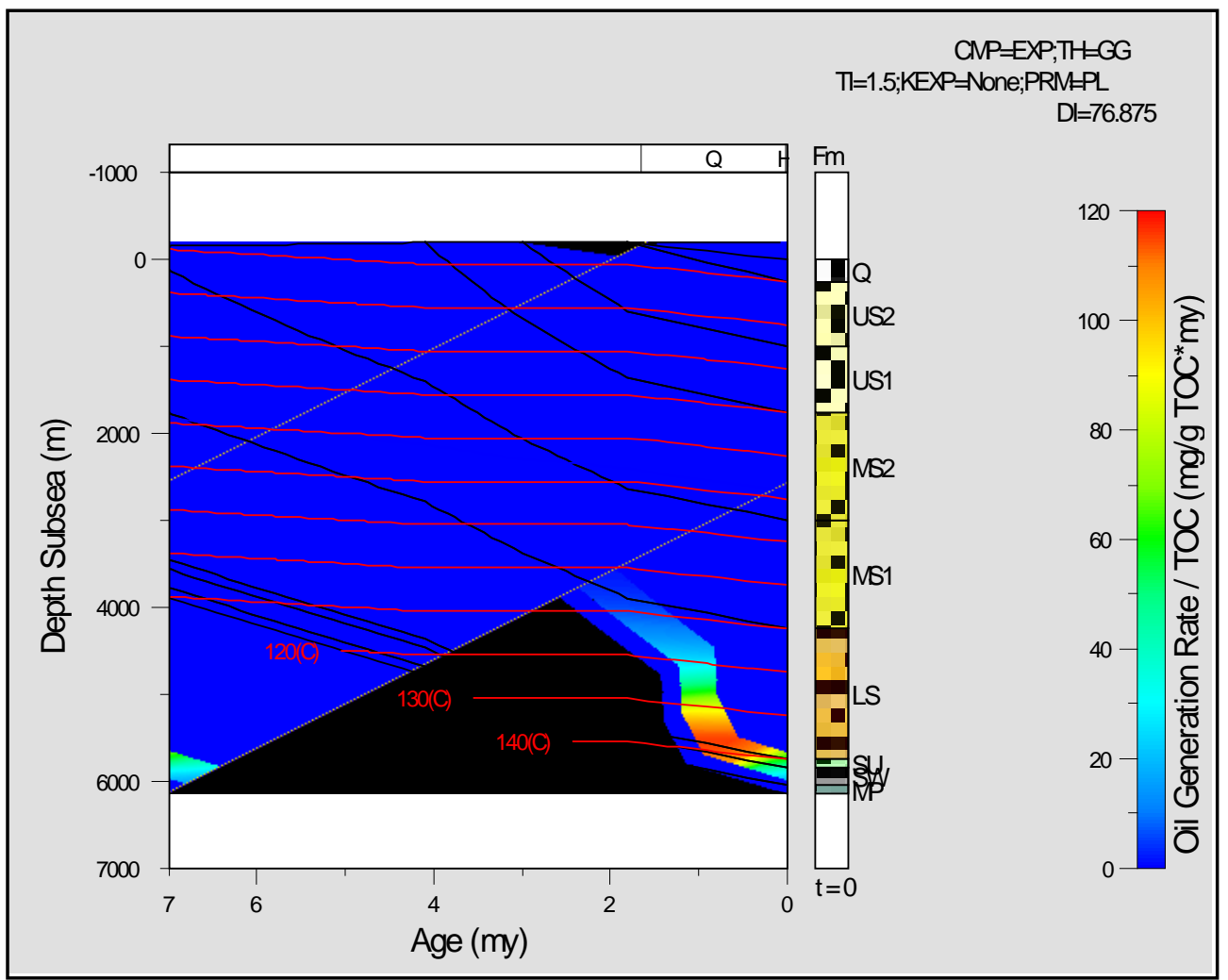

Fig. 10 Oil generation rate, exterior belt (Terai), Exploration Block 2. 


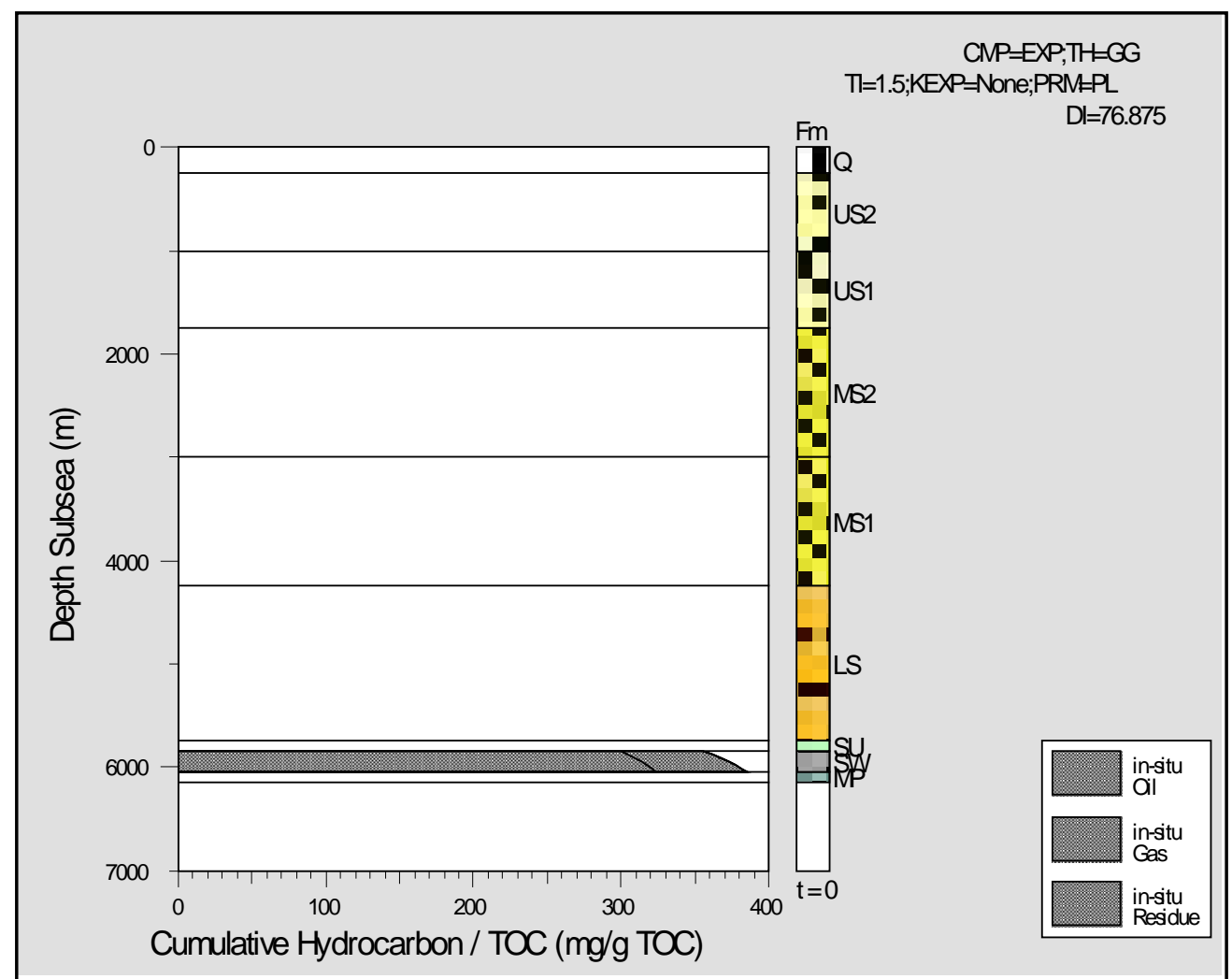

Fig. 11 The Cumulative hydrocarbon/TOC show in-situ oil and associated gas in the Swat Formation. The modeled value is about $300 \mathrm{mg} / \mathrm{g}$ TOC oil and $60 \mathrm{mg} / \mathrm{g}$ TOC gas.

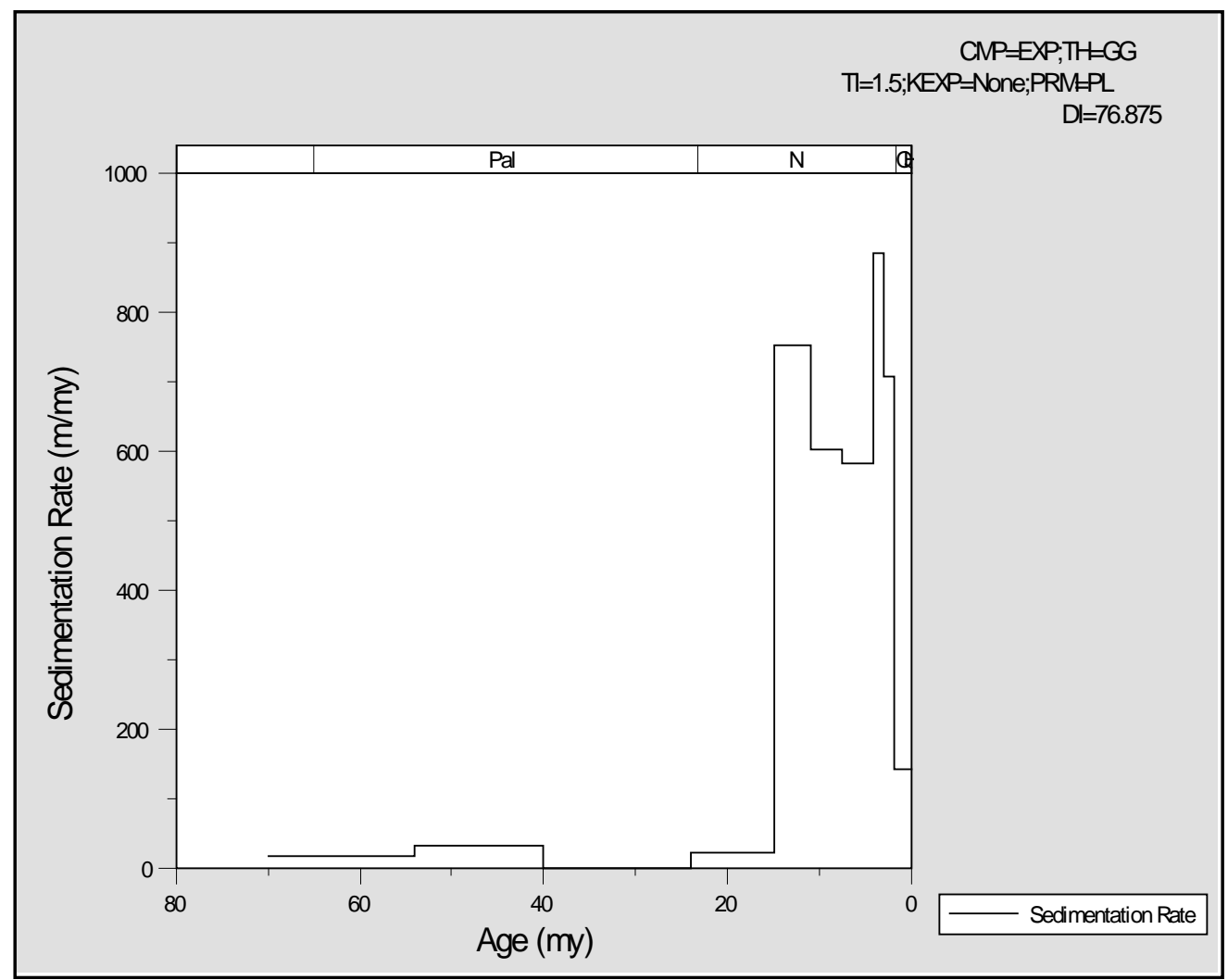

Fig. 12 Sedimentation rates of the foreland basin Nepal revealed from the synthetic well in exterior belt (Terai). 
Table 1 Sedimentation rates of the Siwalik Foreland Basin sediments.

\begin{tabular}{ll}
\hline Age (Ma) & Sedimentation rate \\
\hline $15-11$ & $753 \mathrm{~m} / \mathrm{my}$ \\
$11-7.5$ & $602 \mathrm{~m} / \mathrm{my}$ \\
$7.5-4.1$ & $584 \mathrm{~m} / \mathrm{my}$ \\
$4.1-3$ & $880 \mathrm{~m} / \mathrm{my}$ \\
$3-1.8$ & $707 \mathrm{~m} / \mathrm{my}$ \\
\hline
\end{tabular}

units are probably sealing horizons for this system.

\section{Case Study II: Siwalik Fold and Thrust Belt}

\subsection{Burial History}

The NNE-SSW trending cross section (Figs. 4 and 5 ) and location of the synthetic well in the fold and thrust belt (Fig. 5) are the bases for the model inputs. The Basinmod 1D software faulting module has been used.

The burial history plots for the synthetic well in Fig. 5 of a number of stratigraphic units are drawn. Although the complete statigraphy ranges from Precambrian to present (Fig. 5, Appendix 2a), only

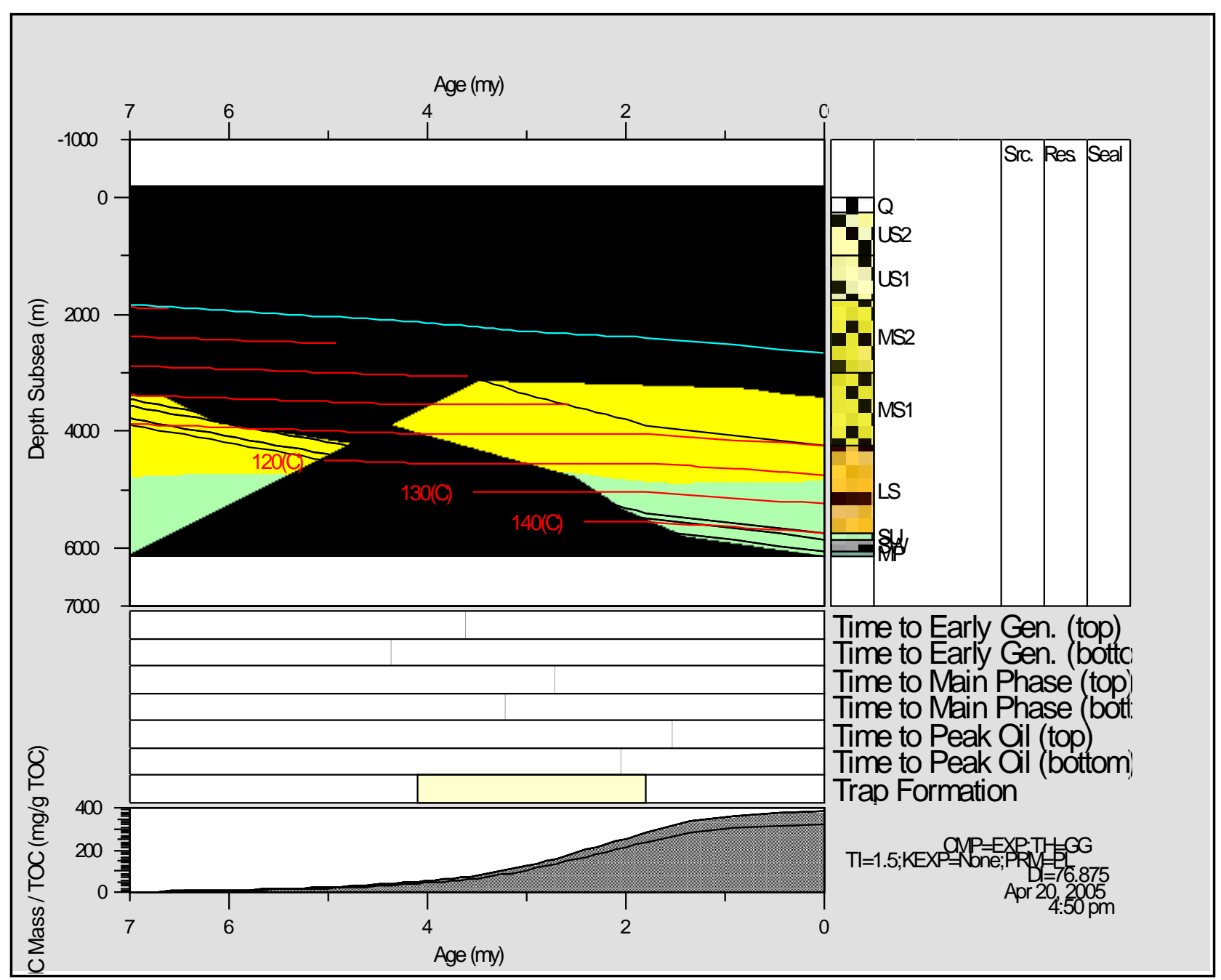

Fig. 13 Total petroleum system, exterior belt (terai), Exploration Block 2. 
the burial history for the last 14 Ma is shown in Fig. 14. The mixed lithological parameters are shown in Appendix 2b and 2c. All other boundary conditions (surface temperature, sea level, sea depth) are taken as same as in Case Study I.

The stratigraphic data were included both for the hanging-wall and footwall blocks. The lithologies, thicknesses and ages of the units were derived from the synthetic well in the geoseismic section (Fig. 5). The removed units due to faulting are defined as missing formations. The amount of section that was removed below the fault is set to $150 \mathrm{~m}$ for the Lakharpata Group. The thrust (MFT) propagation time span is set to 2.4 to $1.8 \mathrm{Ma}$. The FW is defined as the reference fault block.

The four main steps have been described (Fig. 14). The 11-14 Ma periods are the deposition of the Lower Siwalik unit. No regional structures were developed during this time step. Between 11-4.1 Ma, the plots followed the two-step geometry. The first step is due to the deposition of the MS1 between 11-7.5 Ma. Similarly, the second step is due to the deposition of the MS2 between 7.5-4.1 Ma. Between 4.1-1.8 Ma, the plots followed the sharp break between 2.4-1.8 Ma in the HW due to thrusting. This causes the sharp burial of the FW formations during this time step. From 1.8 Ma to present, the plots show further burial. This is due to the sedimentation of the Quaternary basins in the HW.

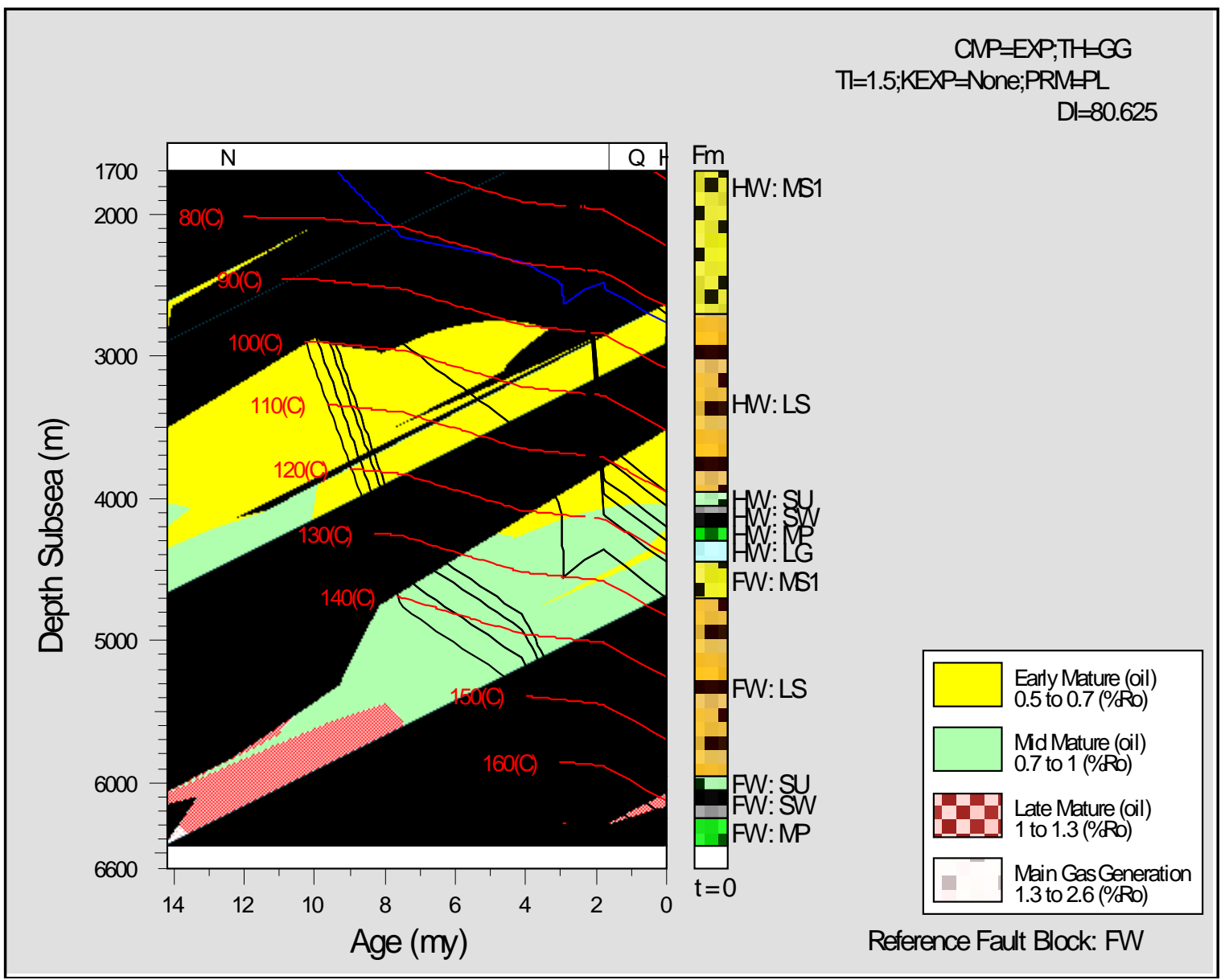

Fig. 14 Burial and thermal history plot for the Siwalik fold and thrust belt. Isotherms are in red, blue is tectonic subsidence curve and stratigraphic trajectories corresponding to the lithological column. Legend in inset indicates the maturity windows. Lower Middle Siwalik (MS1), Lower Siwalik (LS), Suntar Formation (SU), Swat Formation (SW), Melpani Formation (MP), Lakharpata Group (LG), HW and FW refer to units in the hanging-wall and footwall respectively; above and below ca. 4,400 m. 
Maturity windows are found at a shallower depth in the HW starting at about 2,000 m (Fig. 14). The thrust is responsible for the offset of the maturity windows. The footwall Paleogene wedge (Suntar, Swat and Melpani formations) seems to be in late mature stage after faulting.

\subsection{Geothermal Gradient}

The geothermal gradient is set according to the assumption that the sedimentation rates found in the Siwalik fold and thrust belt, would lower the thermal gradient by about $15 \%$ at $5 \mathrm{~km}$ depth and erosion rates in the range would increase the thermal gradient by about 30\% [20]. This implies that the net increase in gradient would be of about $15 \%$ in the fold and thrust belt. A two-step geothermal gradient is assumed. The first step is $20{ }^{\circ} \mathrm{C} / \mathrm{km}$ for up to $2,000 \mathrm{~m}$ depth and the second step below this level is $23{ }^{\circ} \mathrm{C} / \mathrm{km}$. The temperature reaches about $170{ }^{\circ} \mathrm{C}$ at the base of the footwall block at ca. 6,400 m (Fig. 15).

\subsection{Maturity}

The Ro profile (Fig. 16) consists two sublinear segments offset by a sharp break in Ro values. The jump corresponds to the thrust. The hanging-wall Paleogene wedge, consisting of the Suntar, Swat and Melpani formations, have \%Ro range of $0.68-0.72$ at depths of 4,070-4,325 m. The base of the Siwalik unconformity has \% Ro value of 1.14 at 5,960 $\mathrm{m}$ at the footwall block. The base of the Paleogene wedge has \%Ro value of 1.37 at $6,450 \mathrm{~m}$. This implies that the hanging-wall Paleogene wedge is in the early mature stage whereas the footwall Paleogene wedge is in the late mature stage.

\subsection{Porosity}

Porosity at the base of the hanging-wall Lower Siwalik has a value of 0.1 at 3,950 m depth whereas at

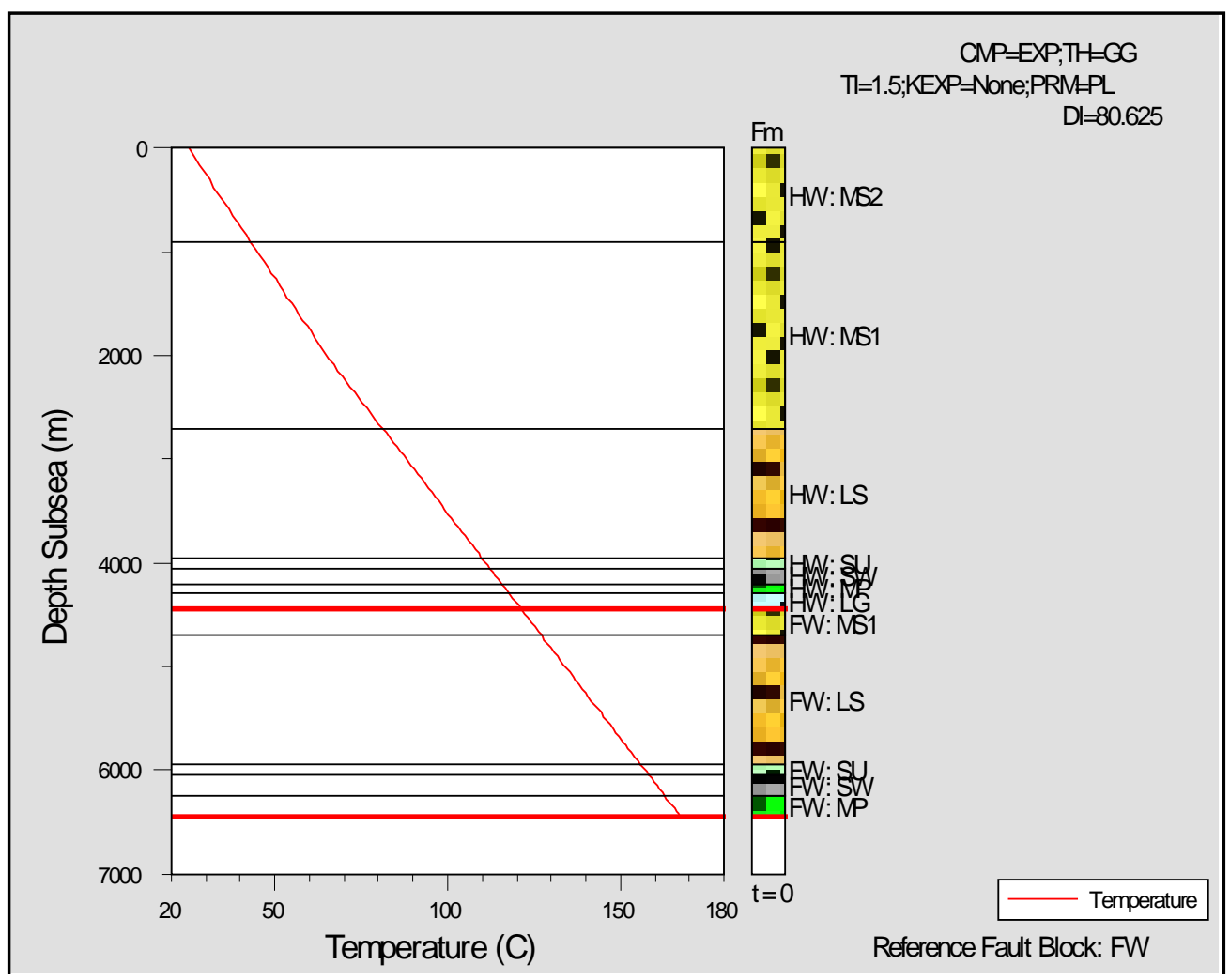

Fig. 15 Geothermal gradient of the Siwalik fold and thrust belt, Exploration Block 2. 


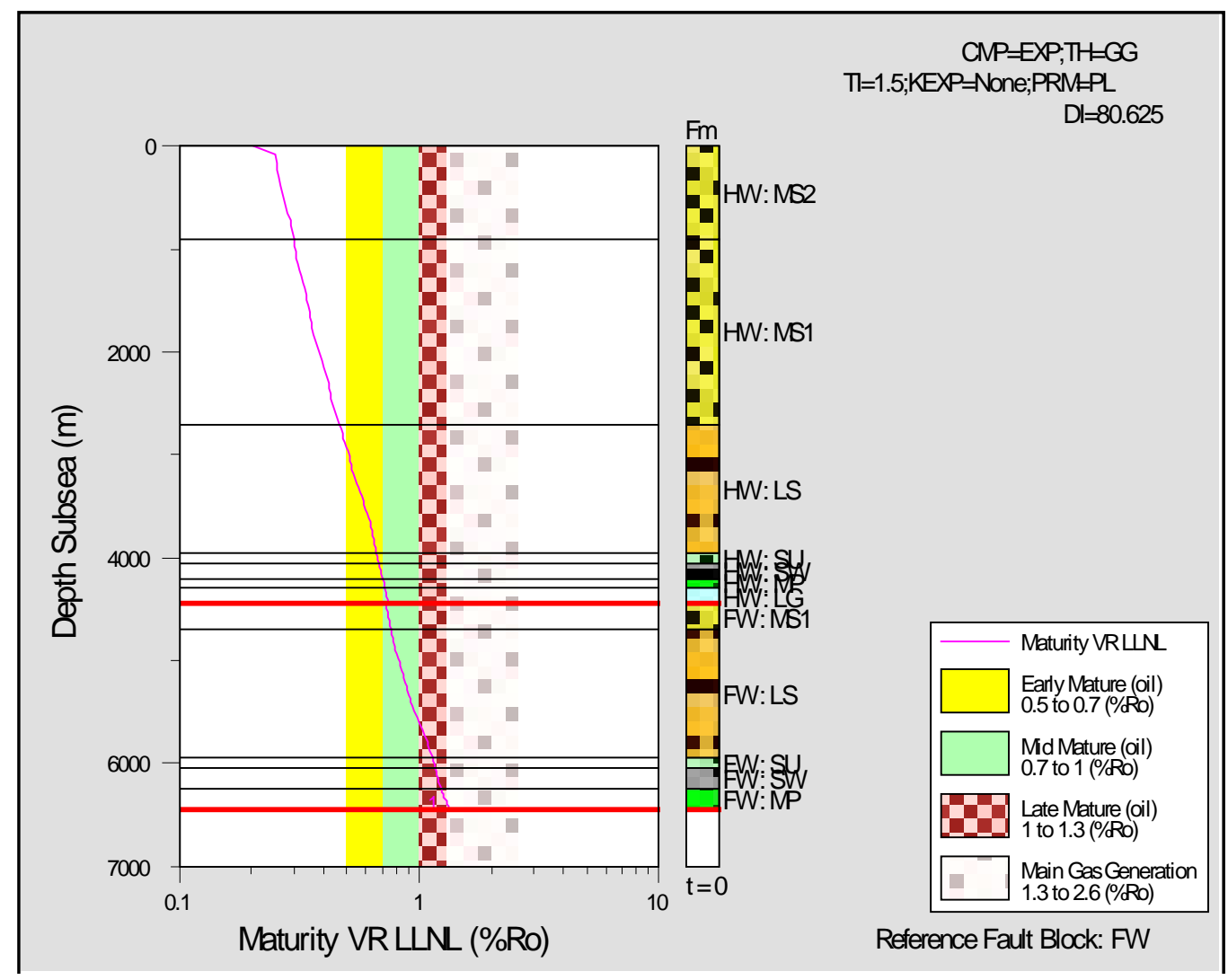

Fig. 16 Vitrinite reflectance profiles for the synthetic well from Siwalik fold and thrust belt, Exploration Block 2.

the footwall it is about 0.04 at 5,960 m. The measured porosity value (0.1) has been used for the sandstones of the Melpani Formation (Fig. 17). The exponentially decreasing trends of porosity plots of the formations are shown in Fig. 9.

\subsection{Oil Generation Rate}

The oil generation rate/TOC depends on the type of kerogen in the Swat shale in this case. The burial depth, temperature and deformation of the region are important considerations for oil generation as seen in Fig. 18.

The burial history model (Fig. 18) shows the footwall Swat Formation has no oil generation capacity after the faulting episode, whereas it has been producing oil since about 8.5 Ma at the depth of 3,800 $\mathrm{m}$. The peak oil generation time step is at about $7 \mathrm{Ma}$ at the depth of about 4,600 m. The hanging-wall Swat Formation has been in the early mature stage of oil generation since faulting (Fig. 18).

\subsection{Cumulative Hydrocarbon}

Fig. 19 is a modeled cumulative hydrocarbon of the hanging wall and footwall Swat Formation. The hanging-wall Swat Formation consists of about 40 $\mathrm{mg} / \mathrm{g}$ TOC oil at about 4,100 $\mathrm{m}$ depth, whereas it has about $415 \mathrm{mg} / \mathrm{g}$ TOC hydrocarbon at about 6,100 m depth of which $330 \mathrm{mg} / \mathrm{g}$ TOC is oil and the remainder is gas and residue. Kerogen forms oil and gas under increasing thermal stress. Kerogen in the Swat shale was assumed to be Type II. The Swat shale in the hanging-wall of the MFT did not reach sufficient maturity to generate hydrocarbons until thrusting and above the thrust it is still in the early mature stage.

\subsection{Petroleum System}

The timing of the major elements of a petroleum system can be presented graphically in a Petroleum System events chart (Fig. 20). The source and reservoir rocks are represented by the Swat and Melpani formations of the Surkhet Group both in the hanging-wall 


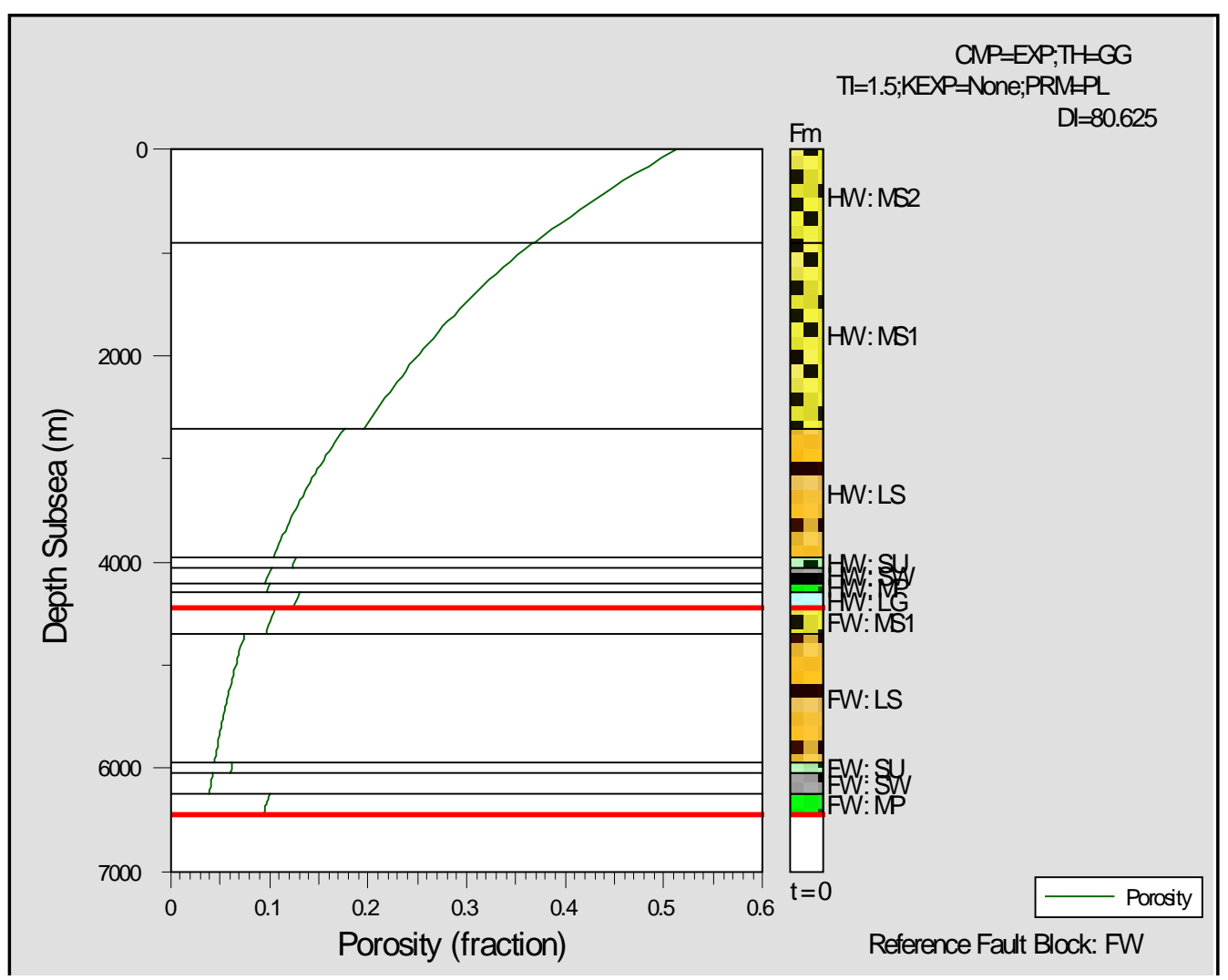

Fig. 17 Porosity plots for the formations in the synthetic well from the Siwalik fold and thrust belt, Exploration Block 2.

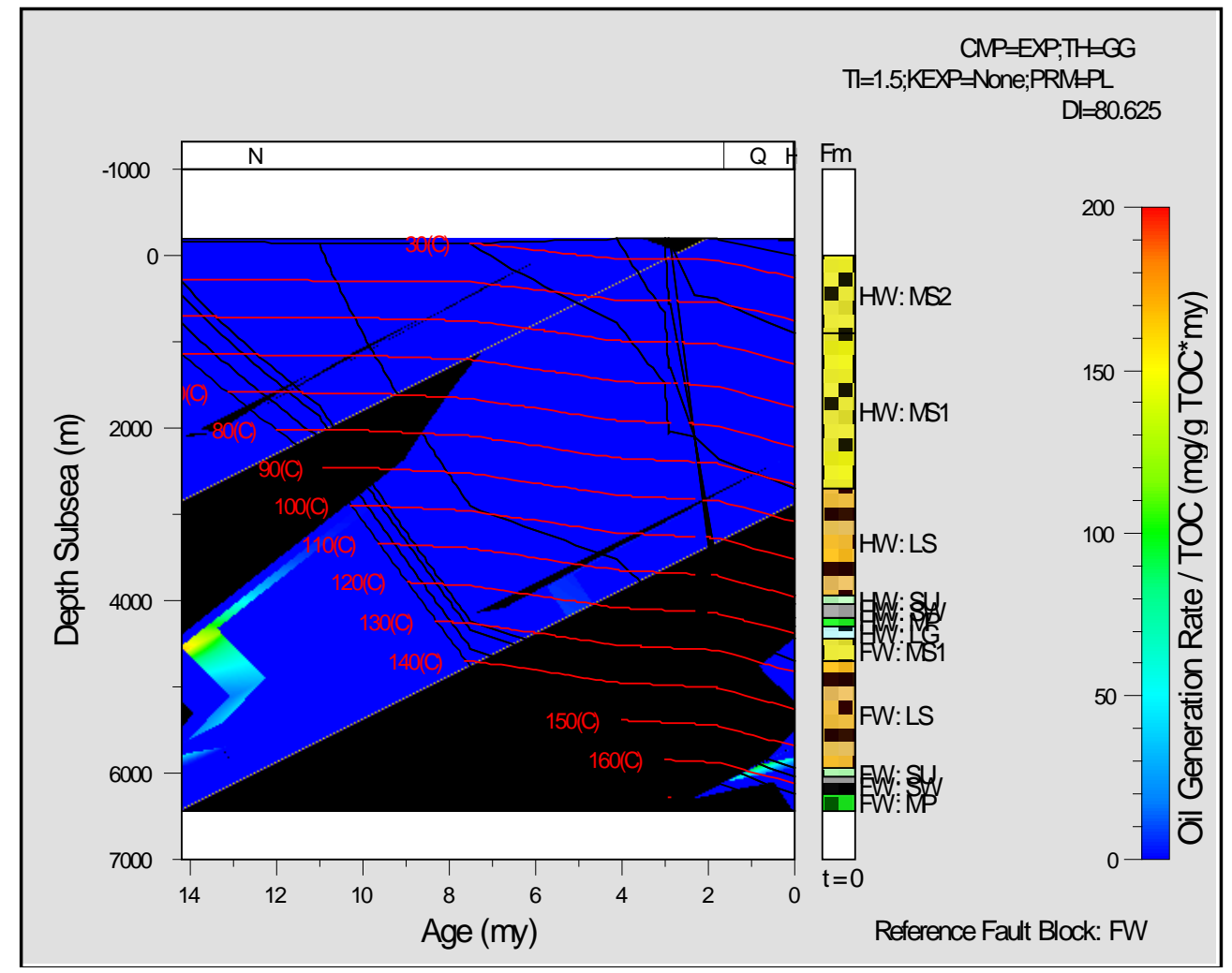

Fig. 18 Oil generation rate of the Siwalik fold and thrust belt, Exploration Block 2. 


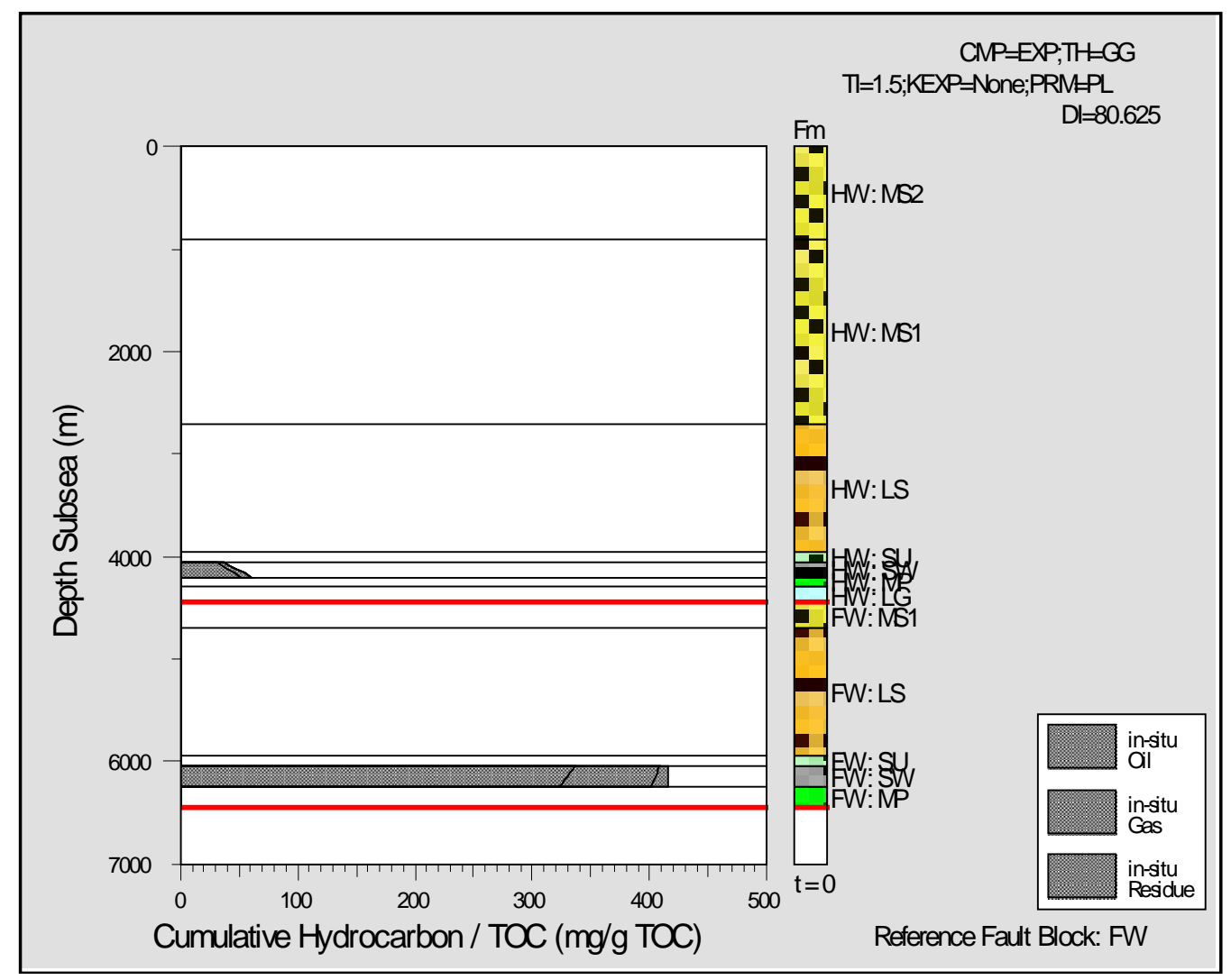

Fig. 19 Cumulative hydrocarbon/TOC in the Swat Formation, Siwalik fold and thrust belt, Exploration Block 2.

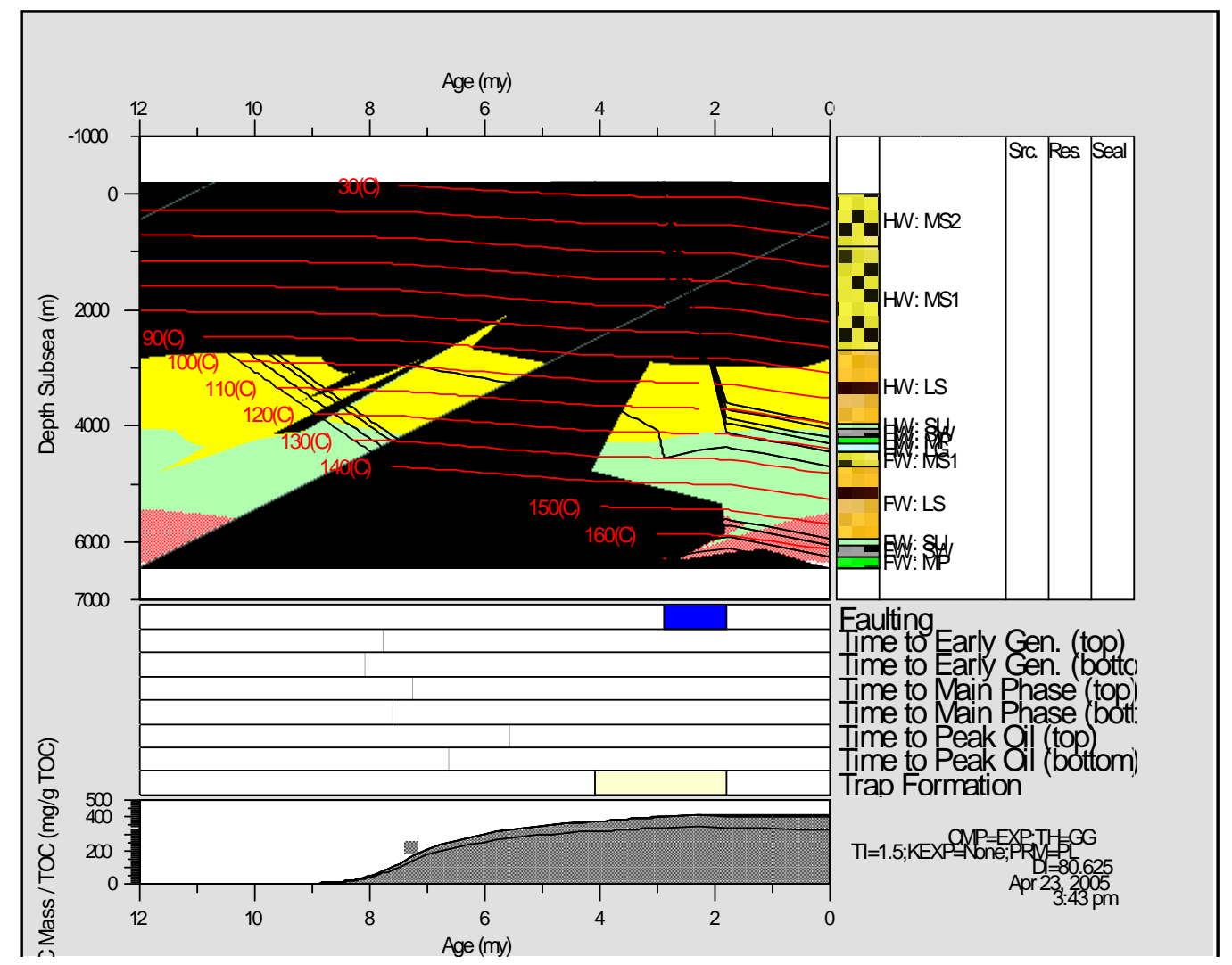

Fig. 20 Petroleum system event chart of the Siwalik fold and thrust belt, Exploration Block 2. 
and footwall. Fig. 20 is a model taking the footwall as a reference block. In the footwall early petroleum generation started since about $8 \mathrm{Ma}$. The time to main phase of oil generation is at about $7 \mathrm{Ma}$ and the peak oil generation spans for about 6.5-5.5 Ma. The time span for the faulting is set to 2.4-1.8 Ma. The structural trap formation time window is set to 4.1-1.8 Ma. The maturity window shows that the late mature stage of oil generation is reached after faulting in the footwall.

\section{Discussion and Conclusion}

The elongate Himalayan peripheral foreland basin has accumulated thick sediments in response to geodynamic processes related to flexural subsidence of the Indian Plate beneath the Tibetan plate. The Nepalese Siwalik Foreland Basin forms the northern part of the greater Indo-Gangetic Foreland Basin in the central sector of the Himalaya. Exploration Block 2 in western Nepal has been chosen for this study of the basin's hydrocarbon prospectivity.

Successful petroleum exploration in the Himalayan foreland basin dates back to a century ago. However, Nepal started exploration activities in 1963, established 10 petroleum exploration blocks in 1985 and the first drilling in the Exterior belt (Terai) in eastern Nepal in 1990 was unsuccessful despite some background gas in the mud. No significant breakthrough has been made in 40 years of exploration. The general challenges and problems of the Siwalik Foreland basin may be approached on several levels. The first is at a basin scale and involves problems of generation and occurrences of hydrocarbons.

BasinMod 1D software with faulting module is a satisfactory method to simulate the temperature evolution and the maturation of organic matter and able to handle relatively simple geometries resulting from deposition, erosion and vertical compaction. Two case studies: the exterior belt (Terai) and Siwalik fold and thrust belt have been performed based on the synthetic wells. The validity of the parameters is based on these two synthetic wells and the geoseismic section itself.
Some of the parameters are used as default. The only measured input is Swat shale (2\%) TOC and Melpani sandstone porosity (10\%).

Comparing the two case histories gives a fair account of the burial history, thermal history, timing of petroleum generation and expulsion in relation to the source rocks. The geohistory curves from Exterior belt show rapid sedimentation and tectonic subsidence whereas the plots from the Siwalik fold and thrust belt show the sharp break between 2.4 and 1.8 Ma in the hanging-wall due to thrusting. This implies the sharp burial of the footwall formations during this period. The geothermal gradient is set according to the Indian wells in the Indo-Gangetic plain for the exterior belt whereas for the Siwalik fold and thrust belt, it is set according to the assumption that the high sedimentation rates found in the Siwalik fold and thrust belt would lower the thermal gradient and erosion rates in the range would increase the thermal gradient. The modeled value for maturity implies that the Surkhet Group lies in the mid mature oil window in the exterior belt. However, for the Siwalik fold and thrust belt, the hanging-wall Paleogene wedge is in the early mature stage, whereas the footwall Paleogene wedge is in the late mature stage. Maturity windows are found at a shallower depth in the hanging-wall. The thrust is responsible for the offset of the maturity windows. The footwall Paleogene wedge seems to be in late mature stage after faulting. The oil generation for the Swat Formation shales starts at $6.3 \mathrm{Ma}$ at 3,988 $\mathrm{m}$ depth to present at 6,050 $\mathrm{m}$ depth with peak oil generation 2.4-1.3 Ma at 5,435-5,782 $\mathrm{m}$ depth in the exterior belt. However, the Siwalik fold and thrust well shows the footwall Swat Formation has no oil generation capacity after the faulting episode, whereas it has been producing oil since about $8.5 \mathrm{Ma}$ at 3,800 m with main phase of oil generation at about $7 \mathrm{Ma}$ at 4,600 $\mathrm{m}$. The hanging-wall Swat Formation has been in the early mature stage of oil generation since faulting. The cumulative hydrocarbon in the Exterior belt is about $360 \mathrm{mg} / \mathrm{g}$ TOC assuming the Swat Formation black 
shales as source rocks. But in the Siwalik fold and thrust belt, the cumulative hydrocarbon of the hanging wall and footwall Swat Formation are about $40 \mathrm{mg} / \mathrm{g}$ TOC oil at about 4,100 m and about $415 \mathrm{mg} / \mathrm{g}$ TOC hydrocarbon at about $6,100 \mathrm{~m}$. This implies that the hydrocarbon potential lies both in the exterior and the Siwalik fold and thrust belt.

The time to early oil generation for top and bottom of the Swat shales is about 3.5 Ma and 4.5 Ma respectively in the exterior belt. The likely time of thrusting of the MFT (2.4-1.8 Ma) and MDT (the Bheri and the Surkhet Thrusts: 3-2.4 Ma) implies that the time of oil generation and the thrusting is contemporaneous in the exterior belt. In the footwall of Siwalik fold and thrust belt, early petroleum generation started since about 8 Ma with peak phase of oil generation at about $6 \mathrm{Ma}$. The time span for the MFT is set to 2.4-1.8 Ma. The maturity window shows that the late mature stage of oil generation is reached after faulting in the footwall. The structural trap formation time window is set to 4.1-1.8 Ma. The hanging-wall is in the early mature stage. This suggests that the distal part of the hanging-wall has most potential for oil generation at relatively shallower level.

The porosity is a function of depth and compaction is interpreted to have no effect on down-hole temperatures in both wells. The modeled porosity trends show that the Middle Siwalik sandstones can be potential reservoirs. The Lower Siwalik shales are less porous compared with the underlying Surkhet Group. These thick shale units are potential sealing horizons for this petroleum system. The source and reservoir rocks are represented by the Swat and Melpani formations of the Surkhet Group both in the hanging-wall and footwall in the Siwalik fold and thrust belt.

Finally, the important findings of this study can be summarized as:

- The burial and thermal history models of the Siwalik Foreland Basin have the characteristics that the Swat shales have the potential of generating hydrocarbon both in the Exterior and Siwalik fold and thrust belts. Assam Province has also the similar history that producing fields and prospects are located mostly in the Assam shelf and hanging-wall of Naga Thrust Front and have Eocene Kopili shales and Oligocene Coal shales are the major source rocks. Similarly, the Potwar Province gas and oil fields are mostly located in the hanging wall of the Salt Range Thrust in the anticlinal traps.

- Source rock maturity is mid mature in the exterior belt, late mature in the footwall and early mature in the hanging-wall in the Siwalik fold and thrust belt. Based on the assessment of maturity in hydrocarbon formation in these wells as a function of time and temperature, the temperature reaches about $150{ }^{\circ} \mathrm{C}$ in the Exterior belt and ca. $115{ }^{\circ} \mathrm{C}$ and $160{ }^{\circ} \mathrm{C}$ at the hanging-wall and footwall of the Siwalik fold and thrust belt at the base of the Swat shales.

- Timing of trap formation is contemporaneous with hydrocarbon generation. The structural traps were formed ca. 4.1-1.8 Ma in the Siwalik Foreland Basin in western Nepal. The basin modeling result shows that the oil generation has started from ca. 4.5 Ma in the exterior belt and ca. $8 \mathrm{Ma}$ in the Siwalik fold and thrust belt. Considering structural traps as the major prospects, the timing of hydrocarbon generation and migration up to the suitable traps is critical for future resource assessment.

- The hydrocarbon prospectivity has more potential relatively at the shallower level in the Siwalik fold and thrust belt. Since the hydrocarbon generation and folding and thrusting in the Siwalik has a significant time gap for potential migration and preservation of hydrocarbon in suitable structural traps. Whereas, the peak oil generation in the exterior belt ca. 2.4-1.3 Ma and the timing of HFT (2.4-1.8 Ma) implies that the migration and preservation of the hydrocarbon is critical for the exterior belt.

\section{Acknowledgement}

I am grateful to NTNU and NORAD, as 
organizations, for providing me opportunity to carry out this research work. I acknowledge the support extended by M/S PRA Inc., USA, for BasinMod software. I am also equally grateful to Mr. Nanda Ram Sthapit, Ex. Director General and Dr. R. B. Shrestha, Ex. Deputy Director General, Department of Mines and Geology, Kathmandu, Nepal.

\section{References}

[1] Kayastha, N. B., Shakya, T. R., Bruneton, A., and Gonnard R. 1998. "Western Nepal Paleogene Wedge May Signal Attractive Play.” Oil and Gas Journal August 17.

[2] Pradhan, U. M. S., Shrestha, R. B., Subedi, D. N., KC, S. B., and Sharma, S. R. 2003. "Geological Map of Petroleum Exploration Block 2.” Karnali, Far Western Nepal, PEPP/HMG.

[3] Friedenreich, O., Slind, O. L., Pradhan U. M. S., and Shrestha R. B. 1994. "Petroleum Geology of Nepal." Canadian Journal of Petreoleum Geophysics 30: 103-14.

[4] Tokuoka, T., Takayasu, K., Yoshida, M., and Hisatomi, K. 1986. "The Churia (Siwalik) Group of the Arung Khola Area, West Central Nepal.” Memoirs of the Faculty of Science Shimane University 20: 135-210.

[5] Dhital, M. R., Gajurel, A. P., Pathak, D., Paudel, L. P., and Kizaki, K. 1995. "Geology and Structure of the Siwaliks and Lesser Himalaya in the Surai Khola-Bardanda Area, Mid-Western Nepal.” Bulletin of the Department of Geology, Tribhuvan University, Kathmandu, 4: 1-70.

[6] Nakayama, K., and Ulak, P. D. 1999. "Evolution of Fluvial Style in the Siwalik Group in the Foothills of the Nepal Himalaya.” Sedimentary Geology 125: 205-24.

[7] Appel, E., Rossler, W., and Corvinus, G. 1991. "Magnetostratigraphy of the Miocene-Pleistocene Surai Khola Siwaliks in West Nepal.” Geophysical Journal International 105: 191-8.

[8] Gautam, P., and Appel, E. 1994. "Magnetic-Polarity Stratigraphy of Siwalik Group Sediments of Tinau Khola Section in West Central Nepal, Revisited.” Geophysical Journal International 117: 223-34.

[9] Harrison, T. M., Copeland, P., Hall, S. A., Quade, J., Burner, S., Ojha, T. P., and Kidd, W. S. F. 1993. "Isotopic Preservation of Himalayan/Tibet Uplift, Denudation, and Climatic Histories of Two Molasse Deposits.” Journal of
Geology 101: 159-77.

[10] Pradhan, U. M. S. 2000. Petroleum Exploration in Nepal. Prabhat, 48-52.

[11] Bashyal, R. P. 1998. "Petroleum Exploration in Nepal." Journal of Nepal Geological Society 18: 19-24.

[12] Upreti, B. N., and Le Fort, P. 1999. "Lesser Himalayan Crystalline Nappes of Nepal: Problem of their Origin.” In: Macfarlane, A., Quade, J., and Sorkhabi, R. Editors, 1999. Geological Society of America Special paper, 328: 225-38.

[13] Panday M. R., Tandukar R. P., Avouac J. P., Vergne J., and Heritier T. 1999. "Seismotectonics of Nepal Himalayas from a Local Seismic Network.” Journal of Asian Earth Sciences 17: 703-13.

[14] Huyghe, P., Mugnier, J. L., Gajurel, A. P., and France-Lanord, C. 2004. "The Record of Climate and Uplift in the Palaeo-Ganga Plain: A Way to Decipher the Interactions between Climate and Tectonics.” Himalaya Journal of Sciences 2: 156-57.

[15] Gautam, P., and Fujiwara, Y. 2000. "Magnetic Polarity Stratigraphy of Siwalik Group Sediments of Karnali River Section in Western Nepal." Geophysics Journal International 142: 812-24.

[16] Wandrey, C. J., Law, B. E., and Ali Sha, H. 2004. Patala-Nammal composite total petroleum system, Kohat-Potwar Geologic Province, Pakistan, U.S. Geological Survey Bulletin 2208-B, U.S. Geological Survey, Petroleum systems and related geologic Studies in Region 8, South Asia, 26.

[17] Wandrey, C. J. 2004. "Sylhet-Kopili/Barail-Tipam Composite Total Petroleum System, Assam Geologic Province, India U.S. Geological Survey.” U.S. Geological Survey Bulletin 2208-D, 16.

[18] DeCelles, P. G., Gehrels, G. E., Quade, J., and Ojha, T. P. 1998a. "Eocene-Early Miocene Foreland Basin Development and the History of Himalayan Thrusting, Western and Central Nepal.” Tectonics 17: 741-65.

[19] Mugnier, J. L., Leturmy, P., Mascle, G., Huyghe, P., Chalaron, E., Vidal, G., Husson, L., and Delcaillau, B. 1999. "The Siwaliks of Western Nepal: I. Geometry and Kinematics.” Journal of Asian Earth Sciences 17: 621-42.

[20] Husson, L., Mugnier, J. L., Leturmy, P., and Vidal, G. 2004. "Kinematics and Sedimentary Balance of the Subhimalayan Zone, West Nepal.” AAPG Memoir 82: 115-30. 
Appendix

Appendix 1a Stratigraphy and related parameters for Exterior belt (Terai).

\begin{tabular}{|c|c|c|c|c|c|c|c|c|}
\hline $\begin{array}{l}\text { Formation } \\
\text { or } \\
\text { Event Name }\end{array}$ & Type & $\begin{array}{l}\text { Begin } \\
\text { Agc } \\
\text { [my] }\end{array}$ & $\begin{array}{l}\text { Top } \\
\text { Depth } \\
\text { [m] }\end{array}$ & $\begin{array}{l}\text { Present } \\
\text { Thick } \\
\text { [m] }\end{array}$ & Lithology & $\begin{array}{c}\text { Organofacies / } \\
\text { Kerogen }\end{array}$ & $\begin{array}{c}\text { Initial } \\
\text { TOC } \\
{[\%]}\end{array}$ & $\begin{array}{l}\text { Measured } \\
\text { Porosity } \\
\text { [0.0-1.0] }\end{array}$ \\
\hline $\mathbf{Q}$ & $\mathrm{F}$ & 1.8 & 0 & 250 & q & & & \\
\hline uS2 & $\mathrm{F}$ & 3 & 250 & 750 & us2 & & & \\
\hline US1 & $\mathrm{F}$ & 4.1 & 1000 & 750 & us1 & & & \\
\hline MS2 & $\mathrm{F}$ & 7.5 & 1750 & 1250 & $\mathbf{m} s 2$ & & & \\
\hline MS1 & $\mathrm{F}$ & 11 & 3000 & 1250 & $\mathrm{~ms} 1$ & & & \\
\hline LS & $\mathrm{F}$ & 15 & 4250 & 1500 & Is & & & \\
\hline su & $\mathrm{F}$ & 24 & 5750 & 100 & su & & & \\
\hline H & H & 40 & & & & & & \\
\hline SW & $\mathrm{F}$ & 54 & 5850 & 200 & sw & Type II [BMOD-1D UNL] & 0.02 & \\
\hline MP & $\mathrm{F}$ & 70 & 6050 & 100 & $\mathrm{mp}$ & & & 0.1 \\
\hline
\end{tabular}

Appendix 1b Mixed parameters for the lithology used for the formations.

\begin{tabular}{|c|c|c|c|c|c|c|c|c|c|c|}
\hline $\begin{array}{l}\text { Lithology } \\
\text { Name }\end{array}$ & ithologs & $\begin{array}{l}\text { Lithology } \\
\text { Pattern }\end{array}$ & $\begin{array}{c}\% \\
\text { Sandstone }\end{array}$ & $\begin{array}{c}\% \\
\text { Siltstone }\end{array}$ & $\begin{array}{c}96 \\
\text { Shale }\end{array}$ & $\begin{array}{c}\% \\
\text { Limestone }\end{array}$ & $\begin{array}{c}\% \\
\text { Delomite }\end{array}$ & $\begin{array}{c}\% \\
\text { User Lith1 }\end{array}$ & User Lith3 & $\begin{array}{c}\text { Total } \\
\%\end{array}$ \\
\hline Sandstone & Yellow & Sandstone & 100 & 0 & 0 & D & $\mathbf{0}$ & 0 & 0 & 100 \\
\hline Siltstone & Green & Siltstone & 0 & 100 & $\mathbf{0}$ & 0 & $\mathbf{0}$ & $\mathbf{0}$ & 0 & 100 \\
\hline Limestone & Blue & Limestone & $\mathbf{0}$ & 0 & 0 & 100 & 0 & 0 & 0 & 100 \\
\hline Dolomite & Blue & Dolomite & $\mathbf{0}$ & 0 & 0 & 0 & 100 & 0 & 0 & 100 \\
\hline Evaporite & Magenta & Evaporite & 0 & 0 & 0 & 0 & $\mathbf{0}$ & 0 & 0 & 100 \\
\hline Igneous & Red & Igneous & 0 & 0 & 0 & 0 & 0 & 0 & 0 & 100 \\
\hline q & & & 20 & 15 & 15 & & & 50 & & 100 \\
\hline$u s 2$ & & & 25 & 5 & 5 & & & 65 & & 100 \\
\hline us1 & & & 20 & 10 & 10 & & & 60 & & 100 \\
\hline ms2 & & & 50 & 25 & 25 & & & & & 100 \\
\hline ms1 & & & 60 & 20 & 20 & & & & & 100 \\
\hline Is & & & 30 & 20 & 50 & & & & & 100 \\
\hline sw & & & 20 & 10 & 60 & 10 & & & & 100 \\
\hline su & & & 60 & 20 & 20 & & & & & 100 \\
\hline $\mathbf{m p}$ & & & 80 & 10 & 10 & & & & & 100 \\
\hline
\end{tabular}

Appendix 1c Mixed parameters.

\begin{tabular}{|c|c|c|c|c|c|c|c|c|c|}
\hline $\begin{array}{l}\text { Lithology } \\
\text { Name }\end{array}$ & $\begin{array}{c}\text { Initial } \\
\text { Porasity } \\
\text { 1D,2D,30 } \\
\text { [fraction] }\end{array}$ & $\begin{array}{c}\text { Peciprocal } \\
\text { Compaction } \\
\text { Factor } \\
1 \mathrm{D} \\
{[1 / \mathrm{km}]}\end{array}$ & $\begin{array}{c}\text { Exponential } \\
\text { Compaction } \\
\text { Factor } \\
1 \mathrm{D} \\
{[1 / \mathrm{km}]}\end{array}$ & $\begin{array}{c}\text { Matrix } \\
\text { Density } \\
\text { 1D,2D,3D } \\
\text { [g/cm³] }\end{array}$ & $\begin{array}{l}\text { Koz-Car } \\
\text { Grain } \\
\text { Size } \\
\text { 10,2D,3D } \\
\text { [mm] }\end{array}$ & $\begin{array}{c}\text { Matrix } \\
\text { Thermal } \\
\text { Conductivity } \\
1 \mathrm{D}, 2 \mathrm{D}, 3 \mathrm{D} \\
{\left[\mathrm{W} / \mathrm{m}^{*} \mathrm{C}\right]}\end{array}$ & $\begin{array}{c}\text { Matrix } \\
\text { Therm Cond } \\
\text { Temp Corr } \\
\text { 1D } \\
\text { [factor] }\end{array}$ & $\begin{array}{c}\text { Matrix } \\
\text { Heat } \\
\text { Capacity } \\
1 \mathrm{D}, 2 \mathrm{D}, 3 \mathrm{D} \\
{\left[\mathrm{kJ} / \mathrm{m} \mathrm{m}^{\star} 3^{\star} \mathrm{C}\right]}\end{array}$ & $\begin{array}{c}\text { Matrix } \\
\text { Therm Cond } \\
\text { Anisotropy } \\
2 D, 3 D \\
\text { [ratio] }\end{array}$ \\
\hline Sandstone & 0.45 & 1.75 & 0.27 & 2.65 & 0.5 & 4.2 & 270 & 2800 & 1.55 \\
\hline Siltstone & 0.55 & 2.2 & 0.41 & 2.67 & 0.0156 & 2 & 170 & 2650 & 1.55 \\
\hline Shale & 0.6 & 2.4 & 0.51 & 2.7 & 0.0004 & 1.5 & -180 & 2100 & 1.55 \\
\hline Limestone & 0.6 & 1.5 & 0.22 & 2.72 & 0.5 & 2.9 & 350 & 2600 & 1.55 \\
\hline Dolomite & 0.6 & 1.5 & 0.22 & 2.85 & 0.5 & 4.8 & 300 & 2600 & 1.55 \\
\hline Evaporite & 0 & 0 & 0 & 2.15 & 0.0004 & 5.4 & 470 & 1750 & 1.55 \\
\hline Coal & 0.9 & 3.5 & 0.7 & 1.8 & 0.0004 & 0.3 & 250 & 950 & 1.55 \\
\hline lgneous & 0 & 0 & 0 & 2.65 & 0.0001 & 2.9 & 380 & 2500 & 1.55 \\
\hline q & 0.488 & 1.915 & 0.327 & 2.634 & 0.10199 & 3.326 & 242.5 & 2672.5 & 1.55 \\
\hline us? & 0.463 & 1.805 & 0.289 & 2.638 & 0.294328 & 4.008 & 314 & 2757.5 & 1.55 \\
\hline us 1 & 0.475 & 1.86 & 0.308 & 2.636 & 0.173258 & 3.652 & 281 & 2715 & 1.55 \\
\hline ms2 & 0.513 & 2.025 & 0.365 & 2.63 & 0.035341 & 2.761 & 132.5 & 2587.5 & 1.55 \\
\hline $\mathbf{m} s 1$ & 0.5 & 1.97 & 0.346 & 2.632 & 0.060037 & 3.03 & 160 & 2630 & 1.55 \\
\hline lg & 0.52 & 1.875 & 0.322 & 2.661 & 0.084919 & 3.173 & 192 & 2605 & 1.55 \\
\hline su & 0.5 & 1.97 & 0.346 & 2.632 & 0.060037 & 3.03 & 160 & 2630 & 1.55 \\
\hline mp & 0.475 & 1.86 & 0.308 & 2.636 & 0.173258 & 3.652 & 215 & 2715 & 1.55 \\
\hline
\end{tabular}


Appendix 1d Geohistory parameters.

\begin{tabular}{|c|c|c|c|c|c|}
\hline $\begin{array}{l}\text { Time } \\
\text { [mry] }\end{array}$ & $\begin{array}{c}\text { Heat } \\
\text { Flow } \\
{\left[\mathrm{m}^{2} W / \mathrm{m}^{2} 2\right]}\end{array}$ & $\begin{array}{l}\text { Surface } \\
\text { Temp } \\
\text { [C] }\end{array}$ & $\begin{array}{l}\text { Basal } \\
\text { Temp } \\
\text { [C] }\end{array}$ & $\begin{array}{l}\text { Sea } \\
\text { Level } \\
\text { [m] }\end{array}$ & $\begin{array}{c}\text { Sea } \\
\text { Depth } \\
\text { [m] }\end{array}$ \\
\hline 1,8 & 50 & 25 & & 0 & -200 \\
\hline 3 & & 25 & & 50 & -150 \\
\hline 4.1 & & 25 & & 50 & -150 \\
\hline 7.5 & & 30 & & 50 & -100 \\
\hline 11 & & 30 & & 50 & -100 \\
\hline 15 & & 30 & & 100 & -75 \\
\hline 24 & & 30 & & 100 & -50 \\
\hline 40 & & 30 & & 150 & 0 \\
\hline 54 & & 30 & & 200 & 50 \\
\hline 70 & & 30 & & 200 & 50 \\
\hline
\end{tabular}

Appendix 2a Stratigraphy for the synthetic well in Siwalik fold and thrust belt.

\begin{tabular}{|c|c|c|c|c|c|c|c|}
\hline $\begin{array}{c}\text { Fault } \\
\text { Block } \\
\text { Name }\end{array}$ & $\begin{array}{c}\text { Formation } \\
\text { or } \\
\text { Event Name }\end{array}$ & Type & $\begin{array}{l}\text { Begin } \\
\text { Agc } \\
\text { [my| }\end{array}$ & $\begin{array}{l}\text { Top } \\
\text { Depth } \\
{[\mathrm{m}]}\end{array}$ & $\begin{array}{l}\text { Present } \\
\text { Thick } \\
\text { [m] }\end{array}$ & $\begin{array}{c}\text { Faulted } \\
\text { Thick Above } \\
\text { [m] }\end{array}$ & $\begin{array}{c}\text { Faulted } \\
\text { Thick Bclow } \\
{[\mathrm{m}]}\end{array}$ \\
\hline HW & MS2 & $\mathrm{F}$ & 7.5 & 0 & 900 & & \\
\hline HW & MS1 & $\mathrm{F}$ & 11 & 900 & 1800 & & \\
\hline HW & LS & $\mathrm{F}$ & 15 & 2700 & 1250 & & \\
\hline HW & su & $\mathrm{F}$ & 24 & 3950 & 100 & & \\
\hline HW & h1 & $\mathrm{H}$ & 40 & & & & \\
\hline HW & SW & $\mathrm{F}$ & 56 & 4050 & 150 & & \\
\hline HW & h2 & $\mathrm{H}$ & 500 & & & & \\
\hline HW & LG & $\mathrm{F}$ & 700 & 4300 & 150 & & 150 \\
\hline $\mathrm{FW}$ & Us2 & $M F$ & 3 & & & 750 & \\
\hline FW & U51 & $M-F$ & 4.1 & & & 750 & \\
\hline FW & MS2 & $M F$ & 7.5 & & & 750 & \\
\hline FW & MS1 & $\mathrm{F}$ & 11 & 4450 & 250 & 2250 & \\
\hline FW & LS & $\mathrm{F}$ & 15 & 4700 & 1250 & & \\
\hline FW & su & $\mathrm{F}$ & 24 & 5950 & 100 & & \\
\hline FW & sw & $\mathrm{F}$ & 56 & 6050 & 200 & & \\
\hline $\mathrm{FW}$ & MP & $\mathrm{F}$ & 70 & 6250 & 200 & & \\
\hline
\end{tabular}

Appendix 2b Mixed parameters.

\begin{tabular}{|c|c|c|c|c|c|c|c|c|c|c|}
\hline $\begin{array}{l}\text { Litholegy } \\
\text { Name }\end{array}$ & $\begin{array}{c}\% \\
\text { Sandstone }\end{array}$ & $\begin{array}{c}\% \\
\text { Siltstone }\end{array}$ & $\begin{array}{c}96 \\
\text { Shale }\end{array}$ & $\begin{array}{c}96 \\
\text { Limestone }\end{array}$ & $\begin{array}{c}\% / \\
\text { Dolomite }\end{array}$ & $\begin{array}{c}\% \\
\text { Evaporite }\end{array}$ & $\begin{array}{c}\% \\
\text { Kerogen }\end{array}$ & $\begin{array}{c}\% \\
\text { Igneous }\end{array}$ & $\begin{array}{c}\text { \% } \\
\text { User Lith1 }\end{array}$ & $\begin{array}{c}\text { Total } \\
\%\end{array}$ \\
\hline Sandstone & 100 & $\mathbf{0}$ & 0 & $\mathbf{0}$ & 0 & 0 & 0 & 0 & $\mathbf{0}$ & 100 \\
\hline Siltstone & 0 & 100 & 0 & 0 & 0 & 0 & o & 0 & 0 & 100 \\
\hline Limestone & 0 & $\mathbf{0}$ & 0 & 100 & $\mathbf{0}$ & D & $\mathbf{0}$ & 0 & 0 & 100 \\
\hline Dolomite & 0 & 0 & 0 & 0 & 100 & $\mathbf{0}$ & 0 & 0 & 0 & 100 \\
\hline Evaporite & o & o & 0 & o & 0 & 100 & 0 & 0 & 0 & 100 \\
\hline Coal & 0 & 0 & 0 & 0 & 0 & 0 & 100 & 0 & 0 & 100 \\
\hline Igneous & 0 & 0 & 0 & 0 & 0 & 0 & 0 & 100 & 0 & 100 \\
\hline q & 20 & 15 & 15 & & & & & & 50 & 100 \\
\hline us2 & 25 & 5 & 5 & & & & & & 65 & 100 \\
\hline us1 & 20 & 10 & 10 & & & & & & 60 & 100 \\
\hline $\mathrm{m} s 2$ & 50 & 25 & 25 & & & & & & & 100 \\
\hline$m s 1$ & 60 & 20 & 20 & & & & & & & 100 \\
\hline Is & 30 & 20 & 50 & & & & & & & 100 \\
\hline $5 g$ & 30 & 20 & 30 & 10 & & & & & 10 & 100 \\
\hline Su & 60 & 20 & 20 & & & & & & & 100 \\
\hline Mp & 80 & 10 & 10 & & & & & & & 100 \\
\hline SWW & 20 & 10 & 60 & 10 & & & & & & 100 \\
\hline
\end{tabular}


Appendix 2c Mixed parameters.

\begin{tabular}{|c|c|c|c|c|c|c|c|c|}
\hline $\begin{array}{l}\text { Lithology } \\
\text { Name }\end{array}$ & $\begin{array}{c}\text { Initial } \\
\text { Porosity } \\
\text { 10,20,30 } \\
\text { [fraction] }\end{array}$ & $\begin{array}{c}\text { Aeciprocal } \\
\text { Compaction } \\
\text { Factor } \\
1 D \\
{[1 / \mathrm{km}]}\end{array}$ & $\begin{array}{c}\text { Exponential } \\
\text { Compaction } \\
\text { Factor } \\
10 \\
{[1 / \mathrm{km}]}\end{array}$ & $\begin{array}{c}\text { Matrix } \\
\text { Density } \\
\text { 1D,2D,3D } \\
{\left[\mathrm{g} / \mathrm{cm}^{+3}\right]}\end{array}$ & $\begin{array}{c}\text { Koz-Car } \\
\text { Grain } \\
\text { Size } \\
\text { 1D,20,3D } \\
\text { [mm] }\end{array}$ & $\begin{array}{c}\text { Matrix } \\
\text { Thermal } \\
\text { Conductivity } \\
10,20,30 \\
\text { W/m }{ }^{*} \mathrm{C} \mid\end{array}$ & $\begin{array}{c}\text { Matrix } \\
\text { Therm Cond } \\
\text { Temp Corr } \\
\text { 10 } \\
\text { ffactor] }\end{array}$ & $\begin{array}{c}\text { Matrix } \\
\text { Heat } \\
\text { Capacity } \\
10,20,30 \\
{\left[\mathrm{~kJ} / \mathrm{m}^{-3} 3^{*} \mathrm{C}\right.}\end{array}$ \\
\hline Sandstone & 0.45 & 1.75 & 0.27 & 2.65 & 0.5 & 4.2 & 270 & 2800 \\
\hline Siltstone & 0.55 & 2.2 & 0.41 & 2.67 & 0.0156 & 2 & 170 & 2650 \\
\hline Shale & 0.6 & 2.4 & 0.51 & 2.7 & 0.0004 & 1.5 & -180 & 2100 \\
\hline Limestone & 0.6 & 1.5 & 0.22 & 2.72 & 0.5 & 2.9 & 350 & 2600 \\
\hline Dolomite & 0.6 & 1.5 & 0.22 & 2.85 & 0.5 & 4.8 & 300 & 2600 \\
\hline Evaporite & 0 & 0 & 0 & 2.15 & 0.0004 & 5.4 & 470 & 1750 \\
\hline Coal & 0.9 & 3.5 & 0.7 & 1.8 & 0.0004 & 0.3 & 250 & 950 \\
\hline lgneous & 0 & 0 & 0 & 2.65 & 0.0001 & 2.9 & 380 & 2500 \\
\hline$q$ & 0.488 & 1.915 & 0.327 & 2.634 & 0.10199 & 3.326 & 242.5 & 2672.5 \\
\hline us2 & 0.463 & 1.805 & 0.289 & 2.638 & 0.294328 & 4.008 & 314 & 2757.5 \\
\hline us1 & 0.475 & 1.86 & 0.308 & 2.636 & 0.173258 & 3.652 & 281 & 2715 \\
\hline ms2 & 0.513 & 2.025 & 0.365 & 2.63 & 0.035341 & 2.761 & 132.5 & 2587.5 \\
\hline $\mathrm{ms} 1$ & 0.5 & 1.97 & 0.346 & 2.632 & 0.060037 & 3.03 & 160 & 2630 \\
\hline 18 & 0.545 & 2.165 & 0.418 & 2.62 & 0.007069 & 2.194 & 25 & 2420 \\
\hline 59 & 0.53 & 2.01 & 0.365 & 2.636 & 0.029426 & 2.51 & 134 & 2540 \\
\hline $\lg$ & 0.52 & 1.875 & 0.322 & 2.661 & 0.084919 & 3.173 & 192 & 2605 \\
\hline Su & 0.5 & 1.97 & 0.346 & 2.632 & 0.0600 .37 & 3.03 & 160 & 2630 \\
\hline$M p$ & 0.475 & 1.86 & 0.308 & 2.636 & 0.173258 & 3.652 & 215 & 2715 \\
\hline sw & 0.565 & 2.16 & 0.423 & 2.624 & 0.0049 & 2.045 & -2 & 2345 \\
\hline
\end{tabular}

\section{Appendix 3}

1. Exponential porosity reduction method (Sclater and Christie, 1980)

$\phi=\phi_{o} \exp { }^{(-k z)}$

where, $\phi=$ Porosity,

$\phi_{o}=$ Initial porosity,

$\mathrm{k}=$ Compaction factor to adjust for varying compressibilities of different lithologies,

$\mathrm{z}=$ Depth.

2. Tectonic subsidence

$Y=S \frac{\left(\rho_{m}-\rho_{s}\right)}{\left(\rho_{m}-\rho_{w}\right)}-\Delta S L\left(\frac{\rho_{w}}{\rho_{m}-\rho_{w}}\right)+\left(W_{d}-\Delta S L\right)$

where, $\mathrm{Y}=$ depth of basement corrected for the sediment load,

$\mathrm{S}=$ Total thickness of sediment column corrected for compaction,

$\rho_{m}=$ Average mantle density,

$\rho_{\mathrm{s}}=$ Average sediment density,

$\rho_{w}=$ Average water density,

$\Delta S L=$ Change of elevation of the mean sea level,

$\mathrm{W}_{\mathrm{d}}=$ Paleo sea depth.

Source: Steckler and Watts, cited in Allen and Allen (1990).

3. Geothermal gradient 
Geothermal gradient $=\frac{d t}{d z}$

4. Arrhenius equation

$$
K=\operatorname{Aexp}\left(\frac{-E}{R T}\right)
$$

where, $\mathrm{K}=$ Reaction Rate,

$\mathrm{A}=$ Arrhenius or frequency constant,

$\mathrm{E}=$ Activation Energy,

$\mathrm{R}=$ Universal Gas Constant,

$\mathrm{T}=$ Absolute Temperature. 